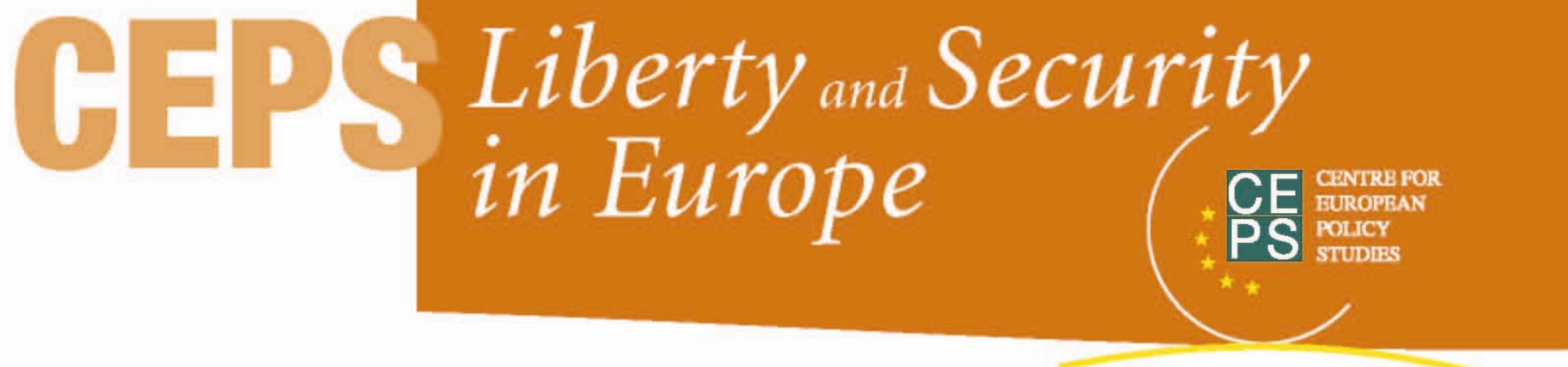

\title{
The Canada-Czech Republic Visa Affair: A test for visa reciprocity and fundamental rights in the European Union
}

\author{
Alejandro Eggenschwiler
}

November 2010

\begin{abstract}
In July 2009, Canada reintroduced the temporary visa requirement for nationals of the Czech Republic. Canadian authorities argued that it was necessary to limit the surge in asylum applications by Czech nationals of Roma origin who had been registered over the previous years. This is the first time that a country whose own nationals enjoy visafree travel to the European Union has reintroduced visas for the nationals of an EU member state. This working paper assesses the implications of this measure for the EU's common visa policy in light of the principle of reciprocity, which lies at its core. It looks in particular at the way in which the EU has reacted to and is currently dealing with this measure in order to see whether the instruments at the EU's disposal to handle such situations have proven to be effective, and whether the necessary solidarity among the member states that should underpin the common visa policy can be said to exist. This paper assesses the Czech Republic-Canada visa affair also from the angle of the fundamental rights situation of Roma as a minority in Europe and the EU's asylum system. In particular, it argues that the prohibition for EU nationals in need of international protection to seek it in any member state, contained in the EU's asylum legislation, may be one of the driving forces behind the exodus of Czech Roma to Canada.
\end{abstract}

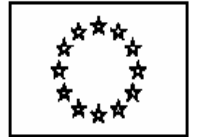

This work was prepared as part of a project on Migration and Asylum in Europe and EUCanada Relations, funded by the European Commission, Directorate-General for External Relations, Relations with the US and Canada. The project studies EU-Canada cooperation on migration and asylum policies. It aims at providing a better understanding of the conceptual, political, sociological and legal elements and dilemmas characterising the development of common European public responses to these issues, and their implications for the relationship between liberty and security in EU-Canada relations.

The CEPS 'Liberty and Security in Europe' publication series offers the views and critical reflections of CEPS researchers and external collaborators on key policy discussions surrounding the construction of the EU's Area of Freedom, Security and Justice. The series encompasses policy-oriented and interdisciplinary academic studies and commentary about the internal and external implications of $J$ ustice and Home Affairs policies inside Europe and elsewhere throughout the world.

Unless otherwise indicated, the views expressed are attributable only to the author in a personal capacity and not to any institution with which he is associated. This publication may be reproduced or transmitted in any form for non-profit purposes only and on the condition that the source is fully acknowledged. 


\section{CONTENTS}

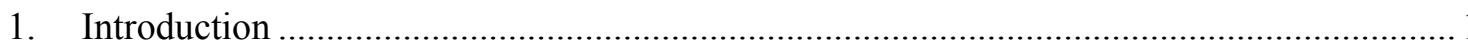

2. Canada's reintroduction of the TRV requirement for the nationals of the Czech Republic: Framing the case

3. EU-Canada cooperation in JHA and their dialogue on visas .............................................. 7

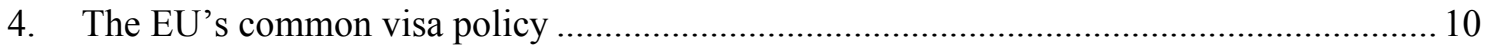

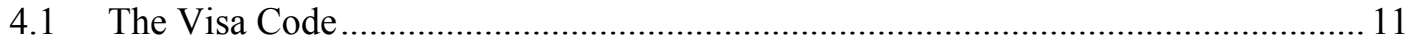

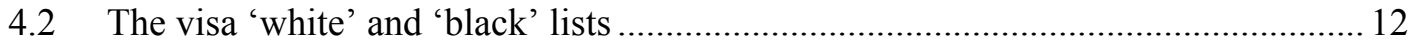

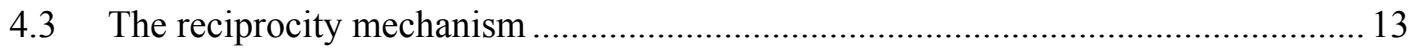

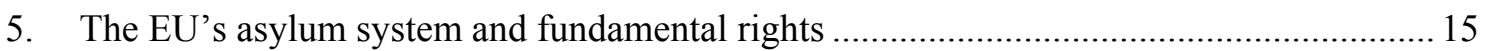

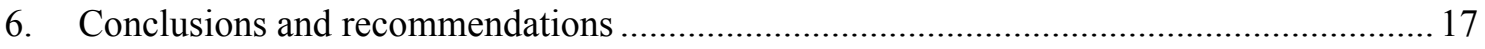

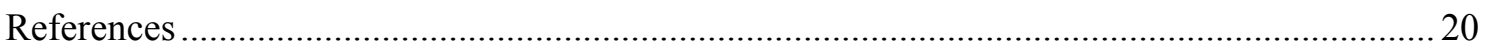

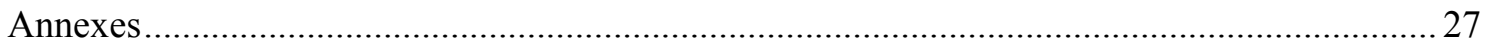

Annex 1. Political and legal developments in the EU-Canada visa dialoguesince the 2004

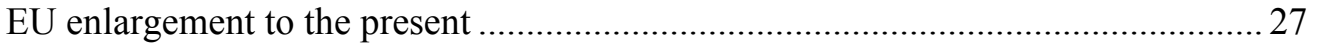

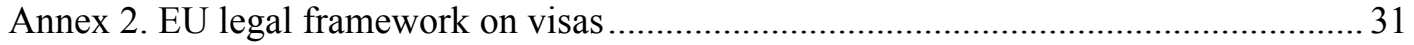




\title{
The Canada-Czech Republic Visa Affair: A test for visa reciprocity and fundamental rights in the European Union
} Alejandro Eggenschwiler*

\author{
CEPS Paper in Liberty and Security in Europe, November 2010
}

\section{Introduction}

On 14 July 2009, Canada reintroduced the temporary resident visa (TRV) requirement for nationals of the Czech Republic due to an increase in asylum applications by Czech nationals of Roma origin. A significant number of those applications were approved. The case is problematic as citizens of the European Union (EU), which is founded on values of equality, respect for fundamental rights and non-discrimination, are fleeing Europe in search of international protection and have obtained it in a third country (Canada). This raises profound questions as to the way in which Roma minorities are being treated in certain member states, as demonstrated by France's expulsions in the summer of 2010 and the restrictive measures adopted in Italy in May 2008. The EU's asylum system might have also played a role in the Canada-Czech Republic visa affair, insofar as it excludes the possibility for EU nationals to seek protection in any member state, based on the assumption that their fundamental rights are always respected and protected.

These developments are having an impact on the external relations of the EU and its visa policy. Strengthening coordination in refugee protection is a priority in EU-Canada cooperation in justice and home affairs (JHA). Besides, visa reciprocity, which means applying to the nationals of third countries the same visa requirements that they apply to EU nationals, is a key principle of the common policy that the EU has been developing in this field since 1999. It has also been an important dimension of the EU-Canada political dialogue since the 2004 EU enlargement, which has resulted so far in the visa obligation being waived for the nationals of all the new member states who had previously been subject to it, including the Czech Republic, except those from Bulgaria and Romania. In this context, the reintroduction of visas on the Czechs clearly constitutes a setback in the process towards the achievement of visa-free travel to Canada for the nationals of all the EU member states.

This paper assesses whether the EU has the capacity to react to Canada's reintroduction of the TRV requirement for the nationals of the Czech Republic in order to restore reciprocity and uphold the common visa policy. Starting from the fundamental rights situation of Roma as a minority in Europe, the paper also looks into the main features of the EU's asylum system in order to identify one of the possible causes behind their decision to leave Europe and seek protection abroad. The paper is structured in five sections. The first section presents the visa affair from a political perspective. It looks at the positions of the main actors involved and at what it is being done at the EU level to restore reciprocity. The second section provides an overview of the origins and developments of the EU-Canada cooperation in JHA, and highlights the advancement in their political dialogue towards the achievement of full reciprocity. The

\footnotetext{
* Alejandro Eggenschwiler is a Research Assistant at the Justice and Home Affairs Section of the Centre for European Policy Studies (CEPS). He wishes to express his gratitude to Sergio Carrera for his guidance and supervision throughout the work, and to Elspeth Guild for her valuable comments. Special thanks also go to the anonymous respondents for their time and availability during interviews.
} 


\section{2 | ALEJANDRO EGGENSCHWILER}

third section outlines the main features of the EU's common visa policy and the results in terms of reciprocity with third countries. The fourth section assesses the EU's asylum system against the 1951 Convention on the status of refugees. The fifth section provides the conclusions and a recommendation.

\section{Canada's reintroduction of the TRV requirement for the nationals of the Czech Republic: Framing the case}

On 13 July 2009, Canada's Immigration and Multiculturalism Minister Jason Kenney announced that Czech nationals would require a visa to travel to Canada as of 14 July $2009 .{ }^{1}$ Canada had first lifted the TRV requirement for the Czech Republic in April 1996 and, due to the surge in the number of asylum claims made by Czech nationals after the lifting, ${ }^{2}$ reintroduced it in October 1997 (see Figure 1). The Czech Republic was not a member of the EU at that time. The visa obligation was eventually lifted on 31 October 2007, following the Czech Republic's accession to the EU in May $2004,{ }^{3}$ and shortly before their participation in the Schengen cooperation as of 21 December 2007.

Figure 1. Refugee claims to Canada by Czech Republic nationals (1983-2009)

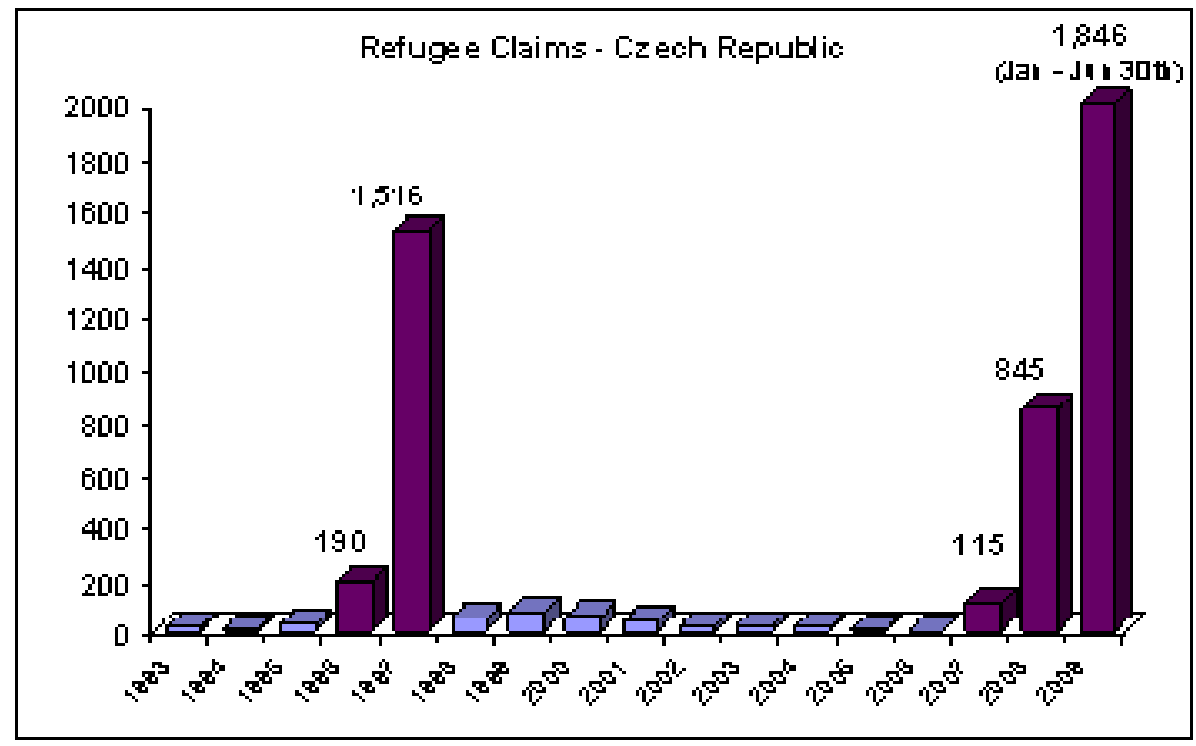

Source: Citizenship and Immigration Canada (CIC).

By reintroducing the TRV obligation for the nationals of the Czech Republic, Canada, a country whose nationals enjoy visa-free travel to the EU, breached the principle of reciprocity, which

\footnotetext{
${ }^{1}$ See Citizenship and Immigration Canada (CIC), News Release, "Canada imposes a visa on the Czech Republic" (http://www.cic.gc.ca/english/department/media/releases/2009/2009-07-13a.asp).

${ }^{2}$ For an analysis of the reasons behind these claims, see J. Tóth (2010), The Incomprehensible Flow of Roma Asylum Seekers from the Czech Republic and Hungary to Canada, CEPS Paper in Liberty and Security in Europe, November.

3 European Commission (2008), Fourth Report from the Commission to the Council and the European Parliament on certain third countries' maintenance of visa requirement in breach of the principle of reciprocity, COM (2008) 486 final/2, Brussels, 9.9.2008, p. 7.
} 
lies at the heart of the EU's common visa policy. ${ }^{4}$ The Czech Republic initiated the EU's reciprocity mechanism ${ }^{5}$ by notifying the Council of the EU (hereinafter, the Council) and the European Commission (hereinafter, the Commission) of the new situation, and asked that "[...] the appropriate measures [be] taken to reassure that all EU citizens on one side and the citizens of Canada on the other side [would] enjoy the same reciprocal regime when crossing the respective borders". 6 In addition, Prague responded to Ottawa's measure by recalling the ambassador and by imposing the visa requirement on the holders of Canadian diplomatic and service passports on 16 July 2009 . $^{7}$

This is the first time that a third country whose nationals enjoy visa-free travel to the EU has reintroduced a visa requirement for the nationals of a member state. Short-term visa policy is an EU competence, which means that member states cannot react individually to the breach of reciprocity by a third country. The Czech case therefore poses the question of whether the EU has the right instruments and the capacity to react to Canada's measure in order to enact the principle of solidarity among member states that should guide the common visa policy. ${ }^{8}$ In this section, we analyse the positions that the actors involved in the case have adopted, and the way in which they are trying to settle the dispute. In doing so, we highlight the role that the EU has played so far in order to restore visa reciprocity and uphold its common visa policy.

Canada justified the reintroduction of the TRV obligation for the Czech nationals on the basis of the need to limit the increase in 1) refugee claims ${ }^{9}$ (see Figure 1), 2) the number of cases of inadmissibility at the borders and 3) the number of interceptions of individuals en route to Canada, by visitors from the Czech Republic, which had been registered from 2006, when the TRV was still in place, to 2008 and $2009 .{ }^{10}$ In a diplomatic note to the Ministry of Foreign Affairs of the Czech Republic, the Canadian authorities said that in the run up to the lifting of the TRV in October 2007, they had warned the Czech authorities of the possibility that an increase in asylum claims would result in its reintroduction, and requested their commitment to enhance cooperation to avoid such situation. ${ }^{11}$ However, behind this measure there is also the

\footnotetext{
${ }^{4}$ Recital 1of Council Regulation (EC) No 539/2001 of 15 March 2001 listing the third countries whose nationals must be in possession of visas when crossing the external borders and those whose nationals are exempt from that requirement (OJ L/1 81 of 21.3.2001).

5 Article 1(4)(a) of Council Regulation (EC) No 851/2005 of 2 June 2005 amending Regulation (EC) No 539/2001 listing the third countries whose nationals must be in possession of visas when crossing the external borders and those whose nationals are exempt from that requirement as regards the reciprocity mechanism (OJ L 141/3, 4.6.2005). For an analysis of the reciprocity mechanism, see subsection 3.3 of this paper.

${ }^{6}$ M. Vicenová (2009), Notification by the Czech Republic concerning visa reciprocity, Ambassador, Permanent Representative of the Czech Republic to the European Union, 14 July 2009 (OJ C 184/2, 6.8.2009).

${ }^{7}$ According to Article 4(1)(a) of Regulation 539/2001, member states may decide unilaterally to grant or not the visa exemption to holders of diplomatic and other official passports.

${ }^{8}$ European Commission (2004), Proposal for a Council Regulation amending Regulation (EC) No 539/2001 as regards the reciprocity mechanism, COM (2004) 437 final/2, Brussels, 19.7.2004, p. 2.

${ }^{9}$ According to the UNHCR, 818 Czech nationals filed asylum claims in Canada in 2008, and 2,016 in 2009 (+134\%). See UNHCR (2010a), Asylum Levels and Trends in Industrialized Countries 2009, 23 March 2010, pp. 32-34 (http://www.unhcr.org/4ba7341a9.html).

${ }^{10} 1 \%$ of the total number of Czech travellers in $2006,6.7 \%$ in 2008 , and $30.1 \%$ in January-May 2009. See European Commission (2009a), Report from the Commission to the Council on the re-introduction of the visa requirement by Canada for citizens of the Czech Republic, COM (2009) 562 final, Brussels, 19.10.2009, p. 6. See also Citizenship and Immigration Canada (CIC), Backgrounder, The visa requirement for the Czech Republic (http://www.cic.gc.ca/english/department/media/backgrounders/2009/2009-07-13a.asp).

${ }^{11}$ Diplomatic Note by the Canadian Embassy in the Czech Republic to the Ministry of Foreign Affairs of the Czech Republic of 19 October 2007. See European Commission (2009a), op. cit., p. 5.
} 


\section{4 | ALEJANDRO EGGENSCHWILER}

assumption, based on the number of refugee claims abandoned or withdrawn by Czech nationals, that a significant number of those claims were not genuine, and that they were rather an attempt by "overwhelmingly economic immigrants" to "bypass the country's immigration system", as Minister Kenney put it. ${ }^{12}$

Nevertheless, the government's stand over the Czech case seems to conflict with that of the Immigration and Refugee Board (IRB) ${ }^{13}$ the body responsible for the decisions on immigration and refugee matters in Canada, for which, based on recognition rates, Czech Roma claiming asylum in Canada qualify as genuine asylum-seekers. According to the Office of the United Nations High Commissioner for Refugees (UNHCR), in 2008, the IRB accepted 84 asylum claims by Czech nationals, out of the 195 cases finalised, with a recognition rate of $43 \%$. Similarly, in 2009, the IRB accepted 90 asylum claims by Czech nationals, out of the 166 cases finalised, with a recognition rate of $54 \%{ }^{14}$ (see also Figures 2 and 3). The reintroduction of the TRV for Czech nationals also raised concerns among Canadian immigration experts. Joseph Allan, an immigration lawyer in Montreal, told the Canadian Broadcasting Corporation (CBC): "By imposing the visa system [...] obviously we're putting an enormous obstacle in the paths of people who genuinely have a fear of persecution in their country." Similarly, Janet Dench, Executive Director of the Canadian Council for Refugees, said that the move would push many asylum-seekers underground: "This is a good day for people smugglers. The Canadian government is giving new business to people who make money out of people's desperate need to get to a country of safety." 15

The Czech authorities believe that "the minority and human rights situation [of Roma] in the Czech Republic is not in itself the cause for the increase of Czech refugee claims in Canada". ${ }^{16}$ In their opinion, it is mainly to be seen as a consequence of the attractiveness of the Canadian asylum system for economically-motivated migrants, also in terms of economic and social benefits for asylum claimants, and of the fact that Canada granted asylum to Czech Roma in the past, thus giving them a further incentive to apply. The Czech authorities also pointed to unemployment and feelings of insecurity among the Roma (due to the rise in right-wing extremism) as additional causes of their exodus. Consequently, the Czech Republic proposed two possible solutions: either that i) Canada modifies its asylum legislation with a view to reducing its attractiveness, or ii) the two countries recognise each other as safe countries of origin. ${ }^{17}$

12 CBC News, “Canada defends visa change for Mexicans, Czechs", 14 July 2009 (http://www.cbc.ca/world/story/2009/07/14/czech-visas-mexico.html), and Citizenship and Immigration Canada (CIC), News Release, "Canada imposes a visa on the Czech Republic", 13 July 2009 (http://www.cic.gc.ca/english/department/media/releases/2009/2009-07-13a.asp).

${ }^{13}$ The IRB is an administrative tribunal, independent from CIC and Canada Border Services Agency (CBSA), which reports to the Parliament. It is made up of three divisions: the Refugee Protection Division, competent for claims for refugee protection made by people already in Canada; the Immigration Division, competent for immigration admissibility hearings; and the Immigration Appeals Division, competent for appeals on immigration matters (http://www.irb.gc.ca/Eng/brdcom/abau/Pages/Index.aspx).

14 UNHCR (2009), 2008 Global Trends: Refugees, Asylum-seekers, Returnees, Internally-displaced and Stateless Persons, Annex, Table 12, 16 June 2009, and UNHCR (2010b), 2009 Global Trends: Refugees, Asylum-seekers, Returnees, Internally-displaced and Stateless Persons, Annex, Table 12, 15 June 2010 (http://www.unhcr.org/4a375c426.html).

\footnotetext{
${ }^{15}$ CBC News, op. cit.

${ }^{16}$ European Commission (2009a), op. cit., p. 7.

${ }^{17}$ Ibid.
} 
Figure 2. Outcome of refugee claims from Czech Republic nationals (2008)

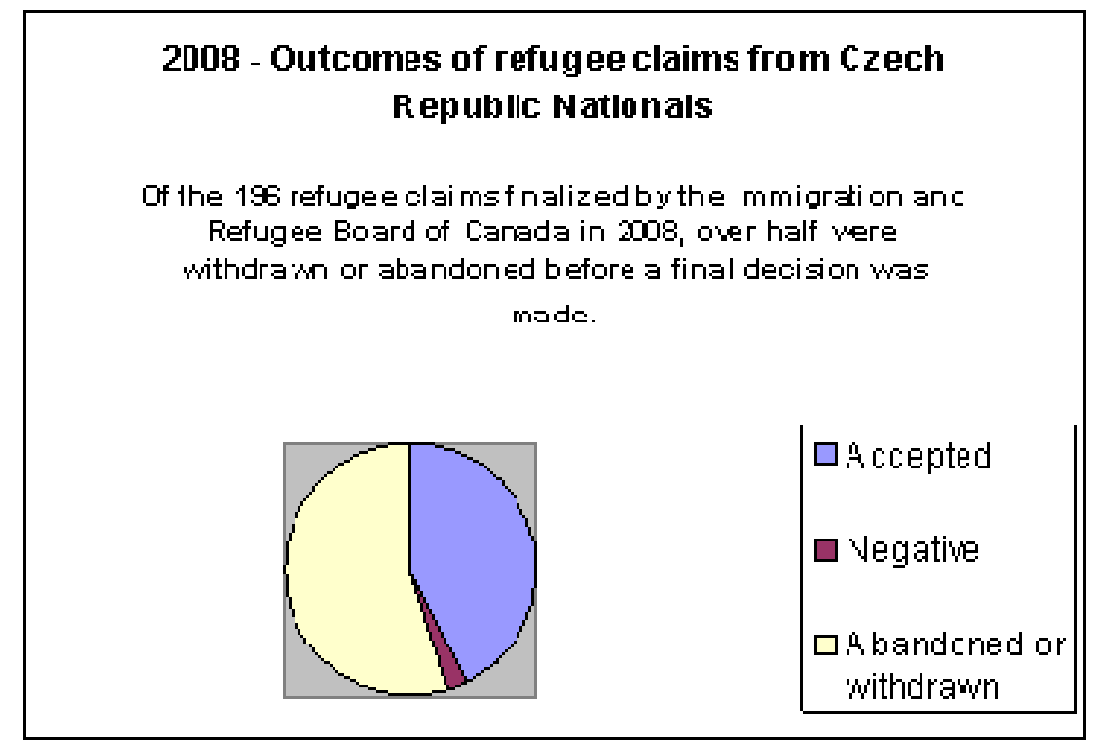

Source: Citizenship and Immigration Canada (CIC).

Figure 3. Outcome of refugee claims from Czech Republic nationals (January-March 2009)

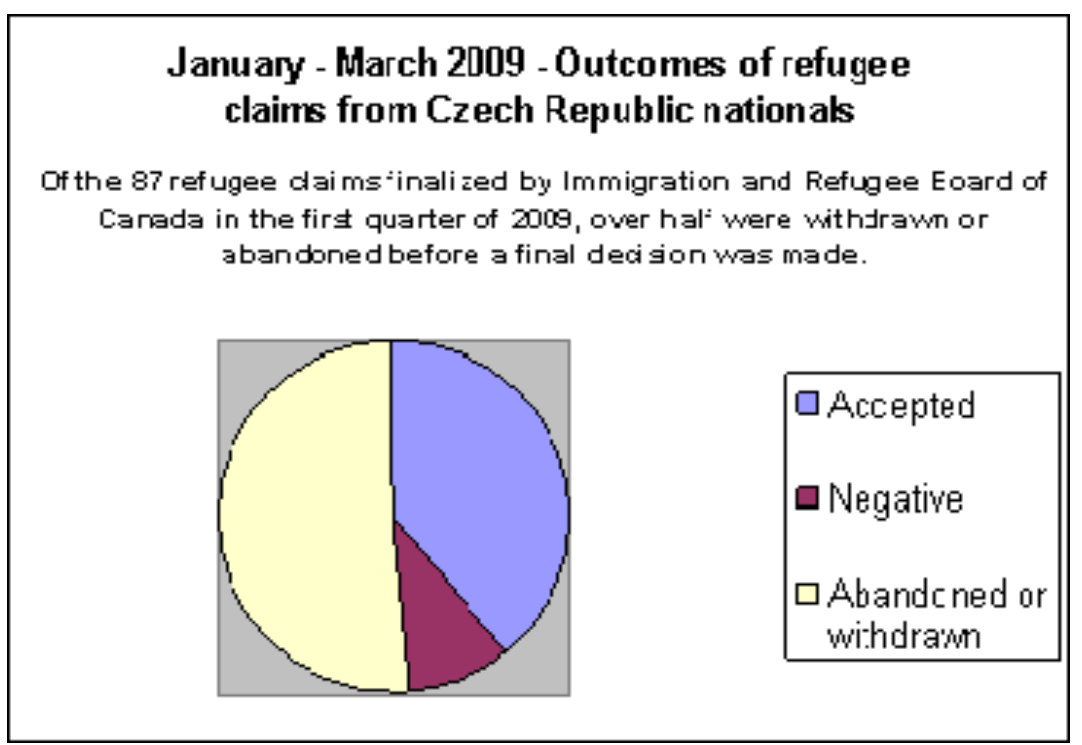

Source: Citizenship and Immigration Canada (CIC).

In search of support from the other member states, the Czech Republic raised the visa issue with Canada at different EU political levels, including the Council and the European Parliament. At the Council level, the issue was brought to the attention of the General Affairs and External Relations Councils of 27 July and 14 September 2009, the JHA Councils of 21 September 2009, 25-26 February, 23 April, 3-4 June and 7-8 October 2010 and the Committee of Permanent Representatives (Coreper) of 23 July 2009. ${ }^{18}$ The result has been a general expression of

\footnotetext{
${ }^{18}$ Press Release, $2958^{\text {th }}$ Council Meeting, External Relations, 12354/09 (Presse 229), Brussels, 27 July 2009 , p. 12; Press Release, $2960^{\text {th }}$ Council Meeting, External Relations, 13027/09 (Presse 260), Brussels, 14 September
} 
solidarity and support from the other member states. The European Parliament adopted a Resolution on the EU-Canada Summit of 5 May 2010, in which it expressed its concern on Canada maintaining the TRV on Bulgaria, the Czech Republic and Romania, and called upon Canadian authorities to lift it as swiftly as possible. ${ }^{19}$ The issue was touched upon, although in terms of the need to achieve full reciprocity between Canada and the EU, also at the Brussels EU-Canada Summit of 5 May 2010. There, Canada's Prime Minister Stephen Harper, the President of the European Council Herman van Rompuy and the President of the Commission José Manuel Barroso reaffirmed their commitment to work towards the achievement of visafree travel to Canada for all the EU citizens. ${ }^{20}$

Under the reciprocity mechanism, the Commission has promptly reacted to Canada's measure, and is currently playing a key role in facilitating the dialogue between the parties. First, they held meetings at expert level with Czech authorities on 14 and 30 July 2009, while the former Director-General of the Directorate-General for Justice Freedom and Security (DG JFS) ${ }^{21}$ met the Canadian Ambassador and the Permanent Representative of the Czech Republic on 24 July $2009 .^{22}$ Then, they presented an ad hoc report to the Council on 19 October 2009, in which they set out two conditions for Canada to fulfil by the end of 2009, under the threat of proposing the introduction of visas for the holders of Canadian diplomatic and service passports. ${ }^{23}$ The first condition, fulfilled by Canada on 21 December $2009,{ }^{24}$ consisted of reinstating visa-issuing facilities in Prague, which had been closed after the lifting of the TRV requirement in $2007 .^{25}$ The second condition consisted of establishing a clear path of measures towards the lifting of the TRV obligation, which is currently being dealt with by the Canada-Czech Republic Experts Working Group (EWG) ${ }^{26}$

Established on 10 September 2009 in Ottawa as a follow-up to two telephone conferences held on 20 and 27 August 2009 between Canadian and Czech authorities, the EWG provides the setting for a regular dialogue aimed at addressing the causes of Canada's reintroduction of the TRV obligation for the nationals of the Czech Republic, and identifying the solutions. ${ }^{27}$ The Czech delegation to the EWG comprises representatives of the Ministries of Interior and of Foreign Affairs, as well as of the Czech embassy in Canada. The Canadian delegation

2009, p. 8; Press Release, $2962^{\text {nd }}$ Council Meeting, Justice and Home Affairs, 13467/09 (Presse 271), Brussels, 21 September 2009, p. 11; Press Release, $2998^{\text {th }}$ Council Meeting, Justice and Home Affairs, 6855/1/10 REV 1 (Presse 42), Brussels, 25-26 February 2010, p. 9; Press Release, $3008^{\text {th }}$ Council Meeting, Justice and Home Affairs, 8920/10 (Presse 88), Brussels, 23 April 2010, p. 7; Press Release, $3018^{\text {th }}$ Council Meeting, Justice and Home Affairs, 10630/1/10 REV 1 (Presse 161), Luxembourg, 3-4 June 2010, p. 27; and Press Release, $3034^{\text {th }}$ Council Meeting, Justice and Home Affairs, 14423/10 (Presse 262), Luxembourg, 7-8 October 2010, p. 15.

${ }^{19}$ European Parliament (2010a), Resolution of 5 May 2010 on the upcoming EU-Canada Summit on 5 May 2010, P7_TA-PROV(2010)0142.

${ }^{20}$ Press Statement, EU-Canada Summit, Council of the European Union, 9355/10 (Presse 100), Brussels, 5 May 2010, p. 2 (http://www.consilium.europa.eu/uedocs/cms_data/docs/pressdata/en/er/114195.pdf).

${ }^{21}$ On 1 July 2010, the DG for Justice, Freedom and Security was divided into two DGs: a DG for Home Affairs and a DG for Justice and Fundamental Rights. Visa policy falls within the competences of the former.

${ }^{22}$ European Commission (2009a), op. cit., p. 4.

${ }^{23}$ Ibid.

${ }^{24}$ Citizenship and Immigration Canada (CIC), Operational Bulletin 168, "Enhanced visa services offered in the Czech Republic", 18 December 2009 (http://www.cic.gc.ca/English/resources/manuals/bulletins/2009/ ob168.asp\#tphp\%20idtphp).

${ }^{25}$ Since the reintroduction of the TRV in July 2009, Czech nationals seeking to travel to Canada had to apply for visas at the consulate of Canada in Vienna.

${ }^{26}$ European Commission (2009a), op. cit., p. 8.

${ }^{27}$ Ibid. 
comprises representatives of CIC and of the Canadian embassy in the Czech Republic. Representatives of the European Commission's DG for Home Affairs and of the EU Delegation to Canada also participate in the work. The EWG holds its meetings in Ottawa and Prague. ${ }^{28}$

The EWG has held four meetings so far: on 10 September 2009 (Ottawa), 15 March 2010 (Prague), 14 May 2010 (Ottawa) and 20 September 2010 (Prague). At the first meeting, Canada explained its immigration and asylum policies, while the Czech Republic presented its laws and policies on the protection of minorities. At the second meeting, the parties agreed on a path of measures, outlined by the Commission, which should lead to re-establishing reciprocity. These measures include: i) long-term measures aimed at preventing the repetition of the situation that led to the reintroduction of the TRV obligation, whose implementation process has already been launched and ii) short-term measures aimed at addressing the current situation, whose implementation would allow visa reciprocity to be restored before the long-term measures are fully in place. ${ }^{29}$ At the third meeting, the parties agreed on the timeline for the implementation of the above-mentioned measures. At the fourth meeting, the Czech Republic and Canada exchanged information on the progress made in the implementation of the agreed measures. ${ }^{30}$ The Czech delegation emphasised that they expect visa reciprocity to be restored within months, not years. Canadians reassured their counterpart in this regard, but without giving any indication as to a possible date for lifting the visa requirement. However, they announced that an expert visit to the Czech Republic would be conducted in November for the preparation of a country report which is part of the review of their visa policy towards the Czech Republic. The date for the next EWG meeting has not been adopted yet. ${ }^{31}$

\section{EU-Canada cooperation in JHA and their dialogue on visas}

As showed above, the Commission is playing an important role in the dispute over visas between Canada and the Czech Republic. They have also tried to act as Canada's main counterpart in the broader political dialogue around this sensitive policy domain with the EU. In this section, after providing an overview of the origins and the main developments of the EUCanada cooperation in JHA, we will outline the main features of this dialogue and the current results in terms of visa reciprocity between Canada and the EU's member states.

EU-Canada cooperation in JHA started out in the 1990s, following the inception of the Schengen cooperation in Europe. In the 1990 Declaration on Transatlantic Relations, the European Communities, their member states and Canada committed themselves to jointly address "trans-national challenges", including the fight against terrorism, the production and

\footnotetext{
${ }^{28}$ Interviews conducted for the purpose of this paper.

${ }^{29}$ Long-term measures are: i) the implementation of Canada's new asylum system, and ii) the sustained implementation of Roma integration policies in the Czech Republic. Being the works of the EWG confidential, information on the nature of the measures agreed is not publicly available. Interviews conducted for the purpose of this paper.

${ }^{30}$ On 21 December 2009, the government of the Czech Republic adopted the "Concept for Roma Integration for 2010-2013" (Decree 1572), a strategic document containing measures which will help Roma take a full part in the cultural, social, economic and political life. It was accompanied by the "Roma Integration Concept Implementation Plan 2010 - 2013". See OSCE (2010), Report on steps taken by public administration and other bodies to improve the position of the Roma minority in the Czech Republic - September 2010, RC.DEL 126/10, 6 October 2010, p. 10 (http://www.osce.org/documents/osce/2010/10/46897_en.pdf). On 15 June 2010, Canada's House of Commons approved the "Balanced Refugee Reform Act" (Bill C-11). If backed by the Senate too, the Bill would become law no later than 24 months following royal assent. See Citizenship and Immigration Canada (CIC), News Release, "The Balanced Refugee Reform Act moves closer to become law", Ottawa, 15 June 2010 (http://www.cic.gc.ca/english/department/media/releases/2010/2010-06-15a.asp).

${ }^{31}$ Interviews conducted for the purpose of this paper.
} 
consumption of drugs and related activities, such as trafficking and money laundering, as well as large-scale migration and the flow of refugees. ${ }^{32}$ After the incorporation of the Schengen acquis in the EU legal system in 1999, EU-Canada cooperation in JHA took the form of meetings between Canadian experts and their European counterparts at the level of the Committee of Article Thirty-Six (CATS) and the Strategic Committee on Immigration, Frontiers and Asylum (SCIFA). ${ }^{33}$

The strengthening of EU-Canada cooperation in JHA is one of the key dimensions of the 2004 EU-Canada Partnership Agenda, which set out the following objectives: i) strengthening judicial cooperation, through Canada's engagement with Eurojust; ii) formalising cooperation between Canada and Europol; iii) concluding extradition and legal assistance agreements to supplement existing bilateral ones; iv) enhancing cooperation to increase legitimate movement of people; v) furthering cooperation on migration and asylum issues; vi) exchanging good practices concerning the integration of migrants; vii) improving the exchange of information to address irregular migration; viii) enhancing the protection of refugees through increased coordination with the relevant international organisations; and ix) further coordinating policies and procedures on return. ${ }^{34}$ In light of these objectives, EU-Canada cooperation in JHA has resulted in:

- The Advanced Passenger Information/Passenger Name Record (API/PNR) Agreement, signed in October 2005, which enables the CBSA to collect advance data on airline passengers flying into Canada from the $\mathrm{EU} ;^{35}$ and

- The Canada-Europol Cooperation Agreement, signed in November 2005, which provided the framework for the exchange of "strategic, technical and operational information" between the contracting parties, for the detection, prevention, suppression and investigation of crime and terrorism. ${ }^{36}$

Visas have been an important dimension of the broader cooperation in JHA, and the achievement of visa-free travel for the nationals of all EU's member states has been one of the fundamental objectives that the EU has pursued in its relations with Canada. As detailed in Annex 1, this objective has been reiterated at the highest political level at all the EU-Canada summits since 2005. In this context, and under the new reciprocity mechanism introduced the same year, the Commission has played an active role by monitoring and periodically reporting to the European Parliament and the Council on any situation of non-reciprocity with Canada concerning any of the member states. ${ }^{37}$

\footnotetext{
32 Declaration on Transatlantic Relations 1990 (http://www.delcan.ec.europa.eu/en/eu and canada/ official_documents/instruments/eu-ca_dtr_1990.shtml).

${ }^{33}$ Interviews conducted for the purpose of this paper. On the EU-Canada cooperation in JHA, see A. Scherrer et al. (eds) (2010), Mobilité(s) sous Surveillance - Perspectives croissés UE-Canada, Athéna; M.B. Salter (ed.) (2010), Mapping Transatlantic Security Relations - The EU, Canada and the War on Terror, Routledge; and S. Alegre (2008), The EU's External Cooperation in Criminal Justice and Counter-terrorism: An Assessment of Human Rights Implications with a Particular Focus on Cooperation with Canada, CEPS Special Report, September 2008, pp. 10-14 (http://www.ceps.eu/files/book/1705.pdf).

34 EU-Canada Partnership Agenda, EU-Canada Summit, Ottawa, 18 March 2004 (http://ec.europa.eu/external_relations/canada/docs/partnership agenda en.pdf).

${ }^{35}$ For an analysis of the PNR Agreement, see P. Hobbing (2008), Tracing Terrorists: The EU-Canada Agreement in PNR Matters, CEPS Special Report, September (http://www.ceps.eu/files/book/1704.pdf).

36 Cooperation Agreement between the Government of Canada and the European Police Office (http://www.europol.europa.eu/legal/agreements/Agreements/227746.pdf).

${ }^{37}$ Article 1(5) of Council of the European Union (2001), op. cit.
} 
Figure 4. Exceptions to the principle of visa reciprocity between Canada and the EU, October 2010

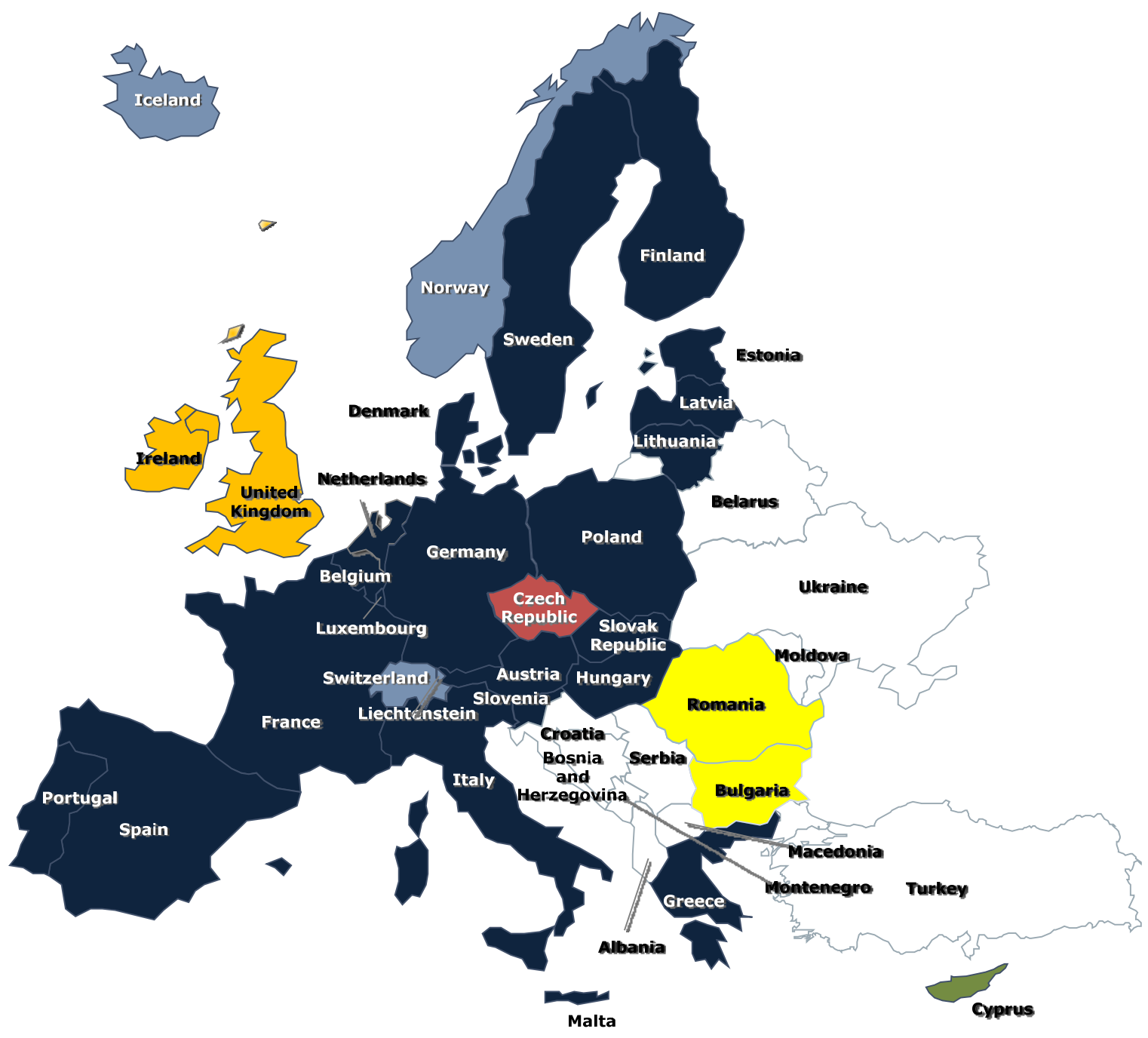

Source: Author's elaboration.

\section{Legend}

- EU member states fully implementing the Schengen acquis on visas whose nationals enjoy visa free travel to Canada

- EU associated states fully implementing the Schengen acquis on visas whose nationals enjoy visa free travel to Canada

- EU member states fully implementing the Schengen acquis on visas whose nationals require a visa to travel to Canada

EU member states not fully implementing yet the Schengen acquis on visas whose nationals require a visa to travel to Canada

- EU member states not fully implementing yet the Schengen acquis on visas whose nationals enjoy visa free travel to Canada

EU member states voluntarily not implementing the Schengen acquis on visas 
In this dialogue, while the Commission has been pushing towards the visa waiver for the nationals of all the member states by invoking the principle of reciprocity, Canada has argued that visa reviews are a process founded on an assessment of the risks and benefits associated with the movement of a country's citizens ${ }^{38}$ and has therefore considered each member state's situation individually. The coordination of visa policies with the United States has played a central role in this approach too. ${ }^{39}$ Overall, notwithstanding the fact that Canada still maintains the TRV obligation for Bulgarians and Romanians, and has reintroduced it for the Czechs, significant progress has been made in this field since the reciprocity mechanism entered into force (see Figure 4 above), as six member states have had the TRV requirement lifted by Canada, after the 2004 enlargement: Estonia (27 September 2006), Latvia (31 October 2007), Hungary, Lithuania, Poland and Slovakia (29 February 2008). ${ }^{40}$

\section{The EU's common visa policy}

In the previous sections we have highlighted the role that the Commission has played so far both in the visa dispute between Canada and the Czech Republic and in the broader dialogue on visas between Canada and the EU. In our view, an active Commission is necessary for the EU to be perceived externally as a single actor in this policy domain, where significant results have been achieved. In this section, we will outline the features of the EU's policy on visas that most characterise it as a common policy, as well as the reciprocity situation vis-à-vis third countries.

The EU's competence on visas is limited to short-stay visas. ${ }^{41}$ Short-term visa policy is a part of a broader strategy for the management of the EU's external borders. Its origins date back to the Schengen cooperation and it covers the EU member states and associated countries that abolished border controls at their internal borders and fully implement the relevant Schengen acquis. ${ }^{42}$ Since the transfer of competences in this field to the former European Community (EC) in 1999, important steps towards a common policy have been taken. First, and most importantly, the EU now disposes of a Visa Code setting out common procedures and conditions for issuing visas. ${ }^{43}$ Second, a series of Council Regulations have established the lists of third countries whose nationals are subject to ('black list') or exempt from ('white list') the short-stay visa requirement for crossing the EU's external borders. ${ }^{44}$ Third, the EU disposes of a

\footnotetext{
${ }^{38}$ See the announcement by Canada's Prime Minister at the EU-Canada Summit in Berlin on 4 June 2007, quoted in European Commission (2007), Third Report from the Commission to the Council and the European Parliament on certain third countries' maintenance of visa requirement in breach of the principle of reciprocity, COM(2007) 533 final, Brussels, 13.9.2007, p. 10. For an analysis of Canada's visa policy, see M. Salter and C. Mutlu (2010), Asymmetric Borders: The Canada-Czech Republic 'Visa War' and the Question of Rights, CEPS Paper in Liberty and Security in Europe, November.

39 European Commission (2006a), First Report from the Commission to the Council and the European Parliament on certain third countries' maintenance of visa requirement in breach of the principle of reciprocity, $\operatorname{COM}(2006) 3$ final, 10.1.2006, p. 13.

${ }^{40}$ Only the nationals of Lithuania and Poland holding biometric passports enjoy visa-free travel to Canada.

${ }^{41}$ Short-stay visas are an authorization issued by a member state with a view to: (a) transit through or an intended stay in the territory of the member states of a duration of no more than three months in any six-month period from the date of first entry in the territory of the member states; (b) transit through the international transit areas of airports of the member states. See Article 2(2) of Regulation (EC) No. 810/2009 of the European Parliament and of the Council of 13 July establishing a Community Code on Visas (Visa Code) (OJ L 243/1, 15.9.2009).

421990 Schengen Convention and Decisions adopted by the Schengen Executive Committee (OJ L 239/19, 22.9.2000).

${ }^{43}$ Regulation (EC) No. 810/2009.
} 
mechanism to react against countries whose nationals enjoy visa-free travel to the EU, which have made the nationals of one or more member states subject to the visa obligation. ${ }^{45}$ Lastly, with the entry into force of the Treaty of Lisbon, this policy domain has been subjected to qualified majority vote in the Council, and the European Parliament has been fully involved in the decision-making procedure, with the same legislative powers as the Council. ${ }^{46}$

\subsection{The Visa Code}

The Visa Code established a common corpus of legislation resulting from the consolidation and development of the Schengen acquis on visas (the relevant provisions of the Convention implementing the Schengen Agreement and the Common Consular Instructions). Its objective is to further harmonise national legislation and handling practices at the consulates of the member states, by setting out common procedures and uniform conditions for issuing short-stay visas. The Commission has drawn up the operational instructions on the practical application of the Visa Code. ${ }^{47}$

The Visa Code regulates the following aspects of the EU's visa policy:

- The procedures and conditions for issuing visas (Title III): The Visa Code identifies the authorities taking part in the procedures relating to visa applications, sets out the general rules and practical modalities for lodging, examining and deciding on visa applications, as well as issuing, annulling and revoking visas.

- The administrative management and organisation of the visa sections of member states' consulates (Title IV): The Visa Code sets out principles that should govern the deployment of resources for examining visa applications as well as the conduct of staff, and regulates the forms of cooperation between the member states' visa-issuing authorities, including the resort to third parties such as external service providers and commercial intermediaries.

- The cooperation between member states' consulates and the European Commission "Local Schengen Cooperation" (Title V): The Visa Code establishes the patterns of cooperation for a harmonised application of the EU's visa policy, especially through the harmonisation of procedures, the dissemination of consistent information to the public, the exchange of information and statistics on visas and regular meetings on operational issues.

The Visa Code provides also standard forms for the visa application (Annex I) and the notification of refusal, revocation or annulment of visas (Annex VI), as well as common instructions for filling in and affixing the visa sticker on travel documents, (Annexes VII and VIII), and a non-exhaustive list of documents to be provided along with the application (Annex II). It introduced also a common list of 12 third countries ${ }^{48}$ whose nationals must be in possession of visas when passing through the international transit areas of airports of the member states (Annex IV), which adds to the white and black lists mentioned above.

\footnotetext{
${ }^{44}$ Council Regulation (EC) No 539/2001 as amended by Council Regulation (EC) No 2414/2001 (OJ L 327/1, 12.12.2001), Council Regulation (EC) No 453/2003 (OJ L 69/10, 13.3.2003), Act of Accession of 2003 (OJ L 236/718, 23.9.2003), Council Regulation (EC) No 851/2005 (OJ L 141/3, 4.6.2005), Council Regulation (EC) No 1791/2006 (OJ L 363/1, 20.12.2006), Council Regulation (EC) No 1932/2006 (OJ L 405/23, 30.12.2006) and Council Regulation (EC) No 1244/2009 (OJ L 336/1, 18.12.2009).

45 Ibid.

${ }^{46}$ Article 77(2) of the Treaty on the Functioning of the European Union (OJ C 83/47, 30.3.2010).

${ }^{47}$ European Commission (2010a), Decision establishing the Handbook for the processing of visa applications and the modification of issued visas, C(2010) 1620 final, Brussels, 19.3.2010.

48 Afghanistan, Bangladesh, Democratic Republic of Congo, Eritrea, Ethiopia. Ghana, Iran, Iraq, Nigeria, Pakistan, Somalia and Sri Lanka.
} 


\subsection{The visa 'white' and 'black' lists}

Currently, the nationals of 125 countries and two entities/territorial authorities are subject to visas, while the nationals of 29 countries and two entities are exempt from it. ${ }^{49}$ The white and the black lists are determined on the basis of reciprocity ${ }^{50}$ and, as detailed in the explanatory memorandum to the Commission's proposal for Council Regulation 539/2001, of three sets of criteria which are weighted variably on a case-by-case basis and which can be grouped under the following three main headings: i) illegal immigration, ii) public policy and iii) international relations $^{51}$ (see Table 1).

Table 1. Criteria for determining the EU visa white and black lists

\begin{tabular}{|c|c|}
\hline $\begin{array}{c}\text { Illegal } \\
\text { immigration }\end{array}$ & $\begin{array}{l}\text { The visas rule constitutes an essential instrument for controlling migratory flows. Here, } \\
\text { reference can be made to a number of relevant sources of statistical information and } \\
\text { indicators to assess the risk of illegal migratory flows (such as information and/or } \\
\text { statistics on illegal residence, cases of refusal of admission to the territory, expulsion } \\
\text { measures, and clandestine immigration and labour measures), to assess the reliability of } \\
\text { travel documents issued by the relevant third country and to consider the impact of } \\
\text { readmission agreements with those countries. }\end{array}$ \\
\hline Public policy & $\begin{array}{l}\text { Conclusions reached in the police cooperation context among others may highlight } \\
\text { specific salient features of certain types of crime. Depending on the seriousness, } \\
\text { regularity and territorial extent of the relevant forms of crime, imposing the visa } \\
\text { requirement could be a possible response worth considering. Threats to public order } \\
\text { may in some cases be so serious as even to jeopardise domestic security in one or more } \\
\text { member states. If the visa requirement was imposed in a show of solidarity by the other } \\
\text { member states, this could again be an appropriate response. }\end{array}$ \\
\hline $\begin{array}{l}\text { International } \\
\text { relations }\end{array}$ & $\begin{array}{l}\text { The option for or against imposing the visa requirement with respect to a given third } \\
\text { country can be a means of underlying the type of relations that the Union is intending to } \\
\text { establish or maintain with it. But the Union's relations with a single country in isolation } \\
\text { are rarely at stake here. Most commonly, it is the relationship with a group of countries, } \\
\text { and the option in favour of a given visa regime also has implications in terms of regional } \\
\text { coherence. The choice of visa regime can also reflect the specific position of a member } \\
\text { state in relation to a third country, to which the other member states adhere in a spirit of } \\
\text { solidarity. The reciprocity criterion, applied by States individually and separately in the } \\
\text { traditional form of relations under public international law, now has to be used by } \\
\text { reason of the constraints of the Union's external relations with third countries. }\end{array}$ \\
\hline
\end{tabular}

\footnotetext{
${ }^{49}$ See Annexes I and II to Council Regulation (EC) 539/2001. On 7 October 2010, the European Parliament backed at first reading the Commission's proposal [COM (2010) 256 final, Brussels, 27.05.2010] to exempt the nationals of Albania and Bosnia-Herzegovina from the visa requirement by the end of 2010 [P7_TC1$\operatorname{COD}(2010) 0137]$. It is to be underlined that France opposed this measure on the grounds of security, notwithstanding the Commission had concluded that Albania and Bosnia-Herzegovina fulfil the requirements for the visa waiver in its assessment report of 14 September 2010 [SEC (2010) 1085 final, Brussels, 14.09.2010, p. 7]. See Le Monde, "La France freine la levée des visas pour les Albanais et les Bosniaques", 01.10 .2010 (http://abonnes.lemonde.fr/cgi-bin/ACHATS/ARCHIVES/ archives.cgi? ID $=50 \mathrm{~d} 95 \mathrm{f} 14 \mathrm{bda} 80 \mathrm{e} 2 \mathrm{c} 79630461 \mathrm{f0bfcfb} 41 \mathrm{c} 7 \mathrm{fe} 126729 \mathrm{~d} 160 \mathrm{c} \& \mathrm{print}=1)$.

${ }^{50}$ See Recital 5 of Regulation (EC) No. 539/2001.

${ }^{51}$ European Commission (2000), Proposal for a Council Regulation listing third countries whose nationals must be in possession of visas when crossing the external borders and those nationals are exempt from that requirement, COM (2000) 27 final, Brussels, 26.1.2000, p. 9. For an analysis of these criteria, see D. Bigo and E. Guild (2005), "Policing at a Distance: Schengen Visa Policies", in D. Bigo and E. Guild (eds), Controlling Frontiers - Free Movement into and within Europe, Aldershot: Ashgate, pp. 244-245, and E. Guild (2003), "The Border Abroad - Visas and Borders Controls", in K. Groenendijk et al. (eds), In Search of Europe's Borders, The Hague: Kluwer Law International, pp. 87-104.
} 


\subsection{The reciprocity mechanism}

The mechanism was introduced in 2001 and revised in 2005. The scheme currently in place combines measures at different levels and of different intensity, which can be triggered by the Commission and the Council.

- First, when a third country whose nationals enjoy visa-free travel introduces a visa requirement on the nationals of a member state, the member state concerned has the obligation to notify in writing the Council and the Commission of the introduction of the visa obligation for its nationals, within 90 days. Such notification must specify the type of visas and the travel documents concerned, as well as the date of implementation of the measure. However, if the third country lifts the visa obligation before the 90 days have elapsed, the notification becomes unnecessary.

- Second, after the notification has been published, the Commission, in consultation with the member state concerned, has to "take steps with the authorities of the third country" in order to re-establish the situation of reciprocity. At this stage of the procedure, the Commission is expected to facilitate the dialogue between the parties and contribute to identify the way ahead.

- Third, within 90 days of the publication of the notification, the Commission has to report to the Council on the situation. If it sees fit, the Commission may propose to the Council the temporary restoration of the visa requirement for the nationals of the third country. The Council can adopt the proposal acting by qualified majority within three months.

The procedure described does not affect the Commission's right to present a proposal for transferring the third country concerned from the white to the black list. However, if a temporary measure has been decided, such proposal must be presented no later than nine months after the measure has entered into force, and must include provisions for lifting it. ${ }^{52}$

Since its introduction in 2001, the reciprocity mechanism had never been triggered, even when the nationals of some member states were subject to the visa obligation by third countries whose nationals enjoyed visa-free travel to the EU. This was primarily the case of Greece with the United States, though there were other cases such as Austria, Finland, Greece, Portugal and Iceland with Brunei; Finland with Venezuela and Iceland with Guatemala. Since the temporary reintroduction of visas for the nationals of the third country concerned was almost automatic, it would have caused third countries to retaliate against all the member states. The mechanism was therefore reviewed in 2005 after the accession of the Central and Eastern European countries to the EU, whose nationals were under the visa obligation towards different countries, in particular Australia, Canada and the United States. Automatic reciprocity was abandoned and the right to initiate the procedure for adopting a temporary measure was transferred from the member state concerned to the Commission.

${ }^{52}$ Article 1(4) of Council Regulation (EC) No. 539/2001 as amended by Council Regulation (EC) No. $851 / 2005$. 
Figure 5. Exceptions to the principle of visa reciprocity between the EU and the rest of the world, October 2010

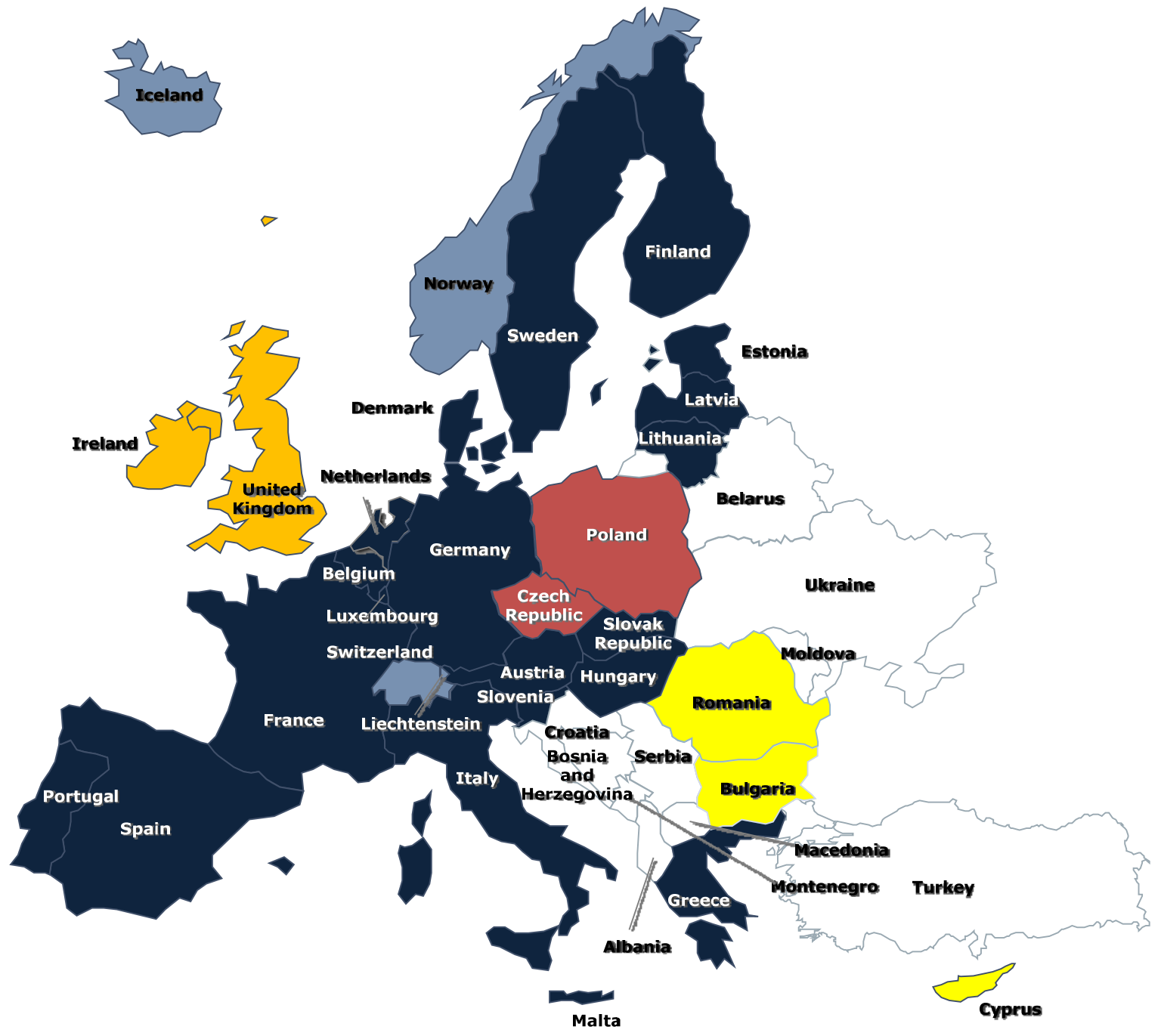

Source: Author's elaboration.

Legend

- EU member states for which visa reciprocity with third countries is in place $\left({ }^{*}\right)$

- EU associated states fully implementing the Schengen acquis on visas for which visa reciprocity with third countries is in place

- EU member states fully implementing the Schengen acquis on visas for which a situation of non reciprocity with one or more third countries exists

EU member states not fully implementing yet the Schengen acquis on visas for which a situation of non reciprocity with one or more third countries exists

- EU member states voluntarily not implementing the Schengen acquis on visas

* See footnote 58 . 
Giving the Commission the right to bring a situation of non-reciprocity at EU level to discuss it and produce an appropriate response has, in our view, made the mechanism more effective. As showed in the reports that the Commission has periodically produced, the new reciprocity mechanism has significantly helped advance towards full reciprocity with the third countries that maintained visa obligations on any of the member states of the enlarged EU. Indeed, while 22 third countries still imposed visas on any of the new member states when they joined the EU on 1 May $2004,{ }^{53}$ only 13 did so in $2005^{54}$ and 8 in $2006 .{ }^{55}$ Following the accessions of Bulgaria and Romania, the number increased again to 11 in $2007,{ }^{56}$ decreased to 7 in $2008^{57}$ and to only 5 in $2009{ }^{58}$ Following the visa waiver agreements between the EU and Brazil, adopted by the Council on 28 September $2010,{ }^{59}$ visa asymmetries exist with only four third countries (Australia, Brunei, Canada and the United States) (see Figure 5 above). ${ }^{60}$

\section{The EU's asylum system and fundamental rights}

So far, we have analysed the Canada-Czech Republic visa case from the angle of the EU's common visa policy and reciprocity. As was highlighted in the first section, Canadian authorities said they reintroduced the TRV obligation for the nationals of the Czech Republic due to the rise in the number of asylum claims by those nationals of Roma origin. The case, therefore, poses questions also as to why the Czech Roma, who are EU nationals, flee Europe in search of protection from a third country (and obtain it). In this section, we try to address this question by looking into the EU's asylum system from a fundamental rights perspective.

Since 1999, the EU has been engaged in a process of legislative harmonisation in the areas of asylum and refugee protection, including measures on the qualification and status of thirdcountry nationals and stateless persons as refugees (Qualification Directive), ${ }^{61}$ the reception of

\footnotetext{
${ }^{53}$ European Commission (2006a), op. cit.

${ }^{54}$ Ibid.

${ }^{55}$ European Commission (2006b), Second Report from the Commission to the Council and the European Parliament on certain third countries' maintenance of visa requirement in breach of the principle of reciprocity, $\operatorname{COM}(2006) 568$ final, Brussels, 3.10.2006.

${ }^{56}$ European Commission (2007), op. cit.

${ }^{57}$ European Commission (2008), op. cit.

${ }^{58}$ European Commission (2009b), Fifth Report from the Commission to the Council and the European Parliament on certain third countries' maintenance of visa requirement in breach of the principle of reciprocity, $\operatorname{COM}(2009) 560$ final, 19.10.2009.

${ }^{59}$ Agreement between the European Union and the Federative Republic of Brazil on short-stay visa waivers for holders of ordinary passports, 13712/10, Brussels, 28 September 2010 (http://register.consilium.europa.eu/pdf/ en/10/st13/st13712.en10.pdf), and Agreement between the European Union and the Federative Republic of Brazil on short-stay visa waivers for holders of diplomatic, services or official passports, 13708/10, Brussels, 28 September 2010 (http://register.consilium.europa.eu/pdf/en/10/st13/st13708.en10.pdf)

${ }^{60}$ On 27 October 2008, Australia introduced the eVisitors system, an electronic system for granting travel authorizations, which applies to the nationals of all the EU member states plus the Schengen associated countries (Iceland, Liechtenstein, Norway and Switzerland). Brunei granted a visa waiver of only 30 days to the nationals of all the EU member states, which can be extended locally for two periods of 30 days up to a total visa waiver stay of 90 days. However, the citizens of the United States enjoy a preferential 90 day stay visa waiver. Canada requires visas from the nationals of Bulgaria, the Czech Republic and Romania. The United States maintain the visa requirement for the nationals of Bulgaria, Cyprus, Poland and Romania. See European Commission (2008), op. cit., pp. 5-6.

${ }^{61}$ Council Directive 2004/83/EC of 29 April 2004 on minimum standards for the qualification and status of third country nationals or stateless persons as refugees or as persons who otherwise need international protection and the content of the protection granted (OJ L 304/12, 30.9.2004).
} 
asylum seekers, ${ }^{62}$ the procedures for granting and withdrawing the refugee status ${ }^{63}$ and the mechanisms determining the member states responsible for analysing the asylum application lodged in one of them. ${ }^{64}$ Further, a European Asylum Support Office (EASO), tasked to enhance and coordinate member states' cooperation in asylum matters, has been recently established. ${ }^{65}$ This legal framework, developed under Art. 63 of the Treaty establishing the European Community, is characterised by the principle of minimum common standards, meaning that regulations and directives set out the lowest protection threshold that member states must comply with. This principle has been overcome by the Treaty of Lisbon, which has provided for the development of a "common policy on asylum, subsidiary protection and temporary protection" [emphasis added], based on common standards and procedures. ${ }^{66}$

A questionable feature of the EU's asylum policy is the presumption - although with some exceptions - that there cannot be asylum-seekers who are nationals of member states. This principle can be inferred from the EU's acquis on asylum outlined above as well as from the Protocol (24) on asylum for nationals of member states of the EU (the Protocol), ${ }^{67}$ attached to the Treaty on the Functioning of the EU, which was originally introduced by the Treaty of Amsterdam in 1999.

The objective of the Qualification Directive is to ensure that member states apply "common criteria" for the identification of persons in need of international protection, by defining common concepts of actors, acts and reasons for persecution. A number of commentators have drawn attention to the provisions whose relationship to the 1951 Convention Relating to the Status of Refugees ${ }^{68}$ (hereinafter, the Geneva Convention) and to fundamental rights appears to be unclear. ${ }^{69}$ However, the most relevant feature of the Qualification Directive to the purpose of this work is its limitation to third country nationals and stateless persons,${ }^{70}$ which appears to be in conflict with Art. 42 of the Geneva Convention, which permits no reservation to the definition of refugee in Art. $1 .^{71}$

Likewise, the abovementioned Protocol (known as the Aznar Protocol) provides that, taking into account the level of protection that EU citizens enjoy under the Treaty, and the criteria that

\footnotetext{
${ }^{62}$ Council Directive 2003/9/EC of 27 January 2003 laying down minimum standards for the reception of asylum seekers (OJ L 31/18, 6.2.2003).

${ }^{63}$ Council Directive 2005/85/EC of 1 December 2005 on minimum standards on procedures in Member States for granting and withdrawing refugee status (OJ L 326/13, 13.12.2005).

${ }^{64}$ Council Regulation (EC) No 343/2003 of 18 February 2003 establishing the criteria and mechanisms for determining the Member State responsible for examining an asylum application lodged in one of the Member States by a third-country national (OJ L 50/1, 25.2.2003).

${ }^{65}$ Regulation (EU) No 439/2010 of the European Parliament and the Council of 19 May 2010 establishing a European Asylum Support Office (OJ L 132/11, 29.5.2010).

${ }^{66}$ Art. 78 of the Treaty on the Functioning of the European Union.

${ }^{67}$ OJ C 83/305, 30.3.2010

${ }^{68} \mathrm{http}: / /$ www.unhcr.org/protect/PROTECTION/3b66c2aa10.pdf

${ }^{69}$ See H. Lambert (2006), "The EU Asylum Qualification Directive, its Impact on the Jurisprudence of the United Kingdom and International Law", International and Comparative Law Quarterly, 55, pp. 161-192; A. Klug (2004), "Harmonization of Asylum in the European Union - Emergence of an EU Refugee System?", German Yearbook of International Law, 47, pp. 594-628; and M.T. Gil-Bazo (2007), "Refugee Status, Subsidiary Protection and the Right to be granted Asylum under EC Law", in A. Baldaccini et al. (eds), Whose Freedom, Security and Justice? EU Immigration and Asylum Law and Policy, Oxford: Hart Publishing, pp. 229-264.

${ }^{70}$ Recital 6 and Article 1.

${ }^{71}$ See G.S. Goodwin-Gill and J. McAdam (2007), The Refugee in International Law, Third Edition, Oxford: Oxford University Press, p. 61.
} 
candidate countries must fulfil in this respect in order to join the EU, each member state shall be regarded as a safe country of origin by other member states with regard to asylum applications made by their nationals. The Protocol is the result of the political pressures by the Spanish government aimed at ensuring that asylum claims made by Basques of Spanish nationality would not be received or considered by any member state. The reason is that, at the time of the negotiation of the Treaty of Amsterdam, a number of asylum applications had been made by Spanish Basques in Belgium. While the Belgian authorities had rejected them, the Belgian courts, in light of the public and judicial concern being expressed in Spain over the activities carried out by the authorities in respect of the Basques, had deemed necessary a review of the applications by individuals claiming that they would be persecuted for their political beliefs if returned to Spain. ${ }^{72}$ Not only is the Protocol based upon a presumption that disregards the situation of EU citizens of Roma origin in certain member states ${ }^{73}$ but it also appears to be in conflict with the wording of the Geneva Convention, namely Art. 3, which expressly requires that the Convention is applied on a non-discriminatory basis, ${ }^{74}$ and with the right to asylum as enshrined in the Charter of fundamental rights of the European Union (Art. 18). ${ }^{75}$

\section{Conclusions and recommendations}

This working paper has analysed Canada's reintroduction of the TRV requirement for the nationals of the Czech Republic on 14 July 2009 from two angles. Firstly, it has looked at the way in which the EU has reacted to and is currently dealing with this measure to restore reciprocity in order to see whether the instruments currently in place in the context of the EU's visa policy to handle such situations have proven to be effective, and whether the necessary solidarity among member states that should underpin the claim of holding a common policy in

\footnotetext{
${ }^{72}$ See E. Guild (2005), “The Legal Framework: Who is Entitled to Move?”, in D. Bigo and E. Guild (eds), op. cit., p. 34.

${ }^{73}$ The situation of Roma in the EU has been the subject of extensive studies, and has been under the attention of the EU institutions and other European organisations, such as the Council of Europe and the Organisation for Security and Cooperation in Europe (OSCE). The findings point to the conclusion that Roma are still subject to racial discrimination in key areas of social life, such as education, employment, housing and health care in a number of EU member states. See European Union Agency for Fundamental Rights (2009a), Annual Report 2009 (http://www.fra.europa.eu/fraWebsite/attachments/FRA-AnnualReport09 en.pdf); European Union Agency for Fundamental Rights (2009b), The situation of Roma EU citizens moving and settling in other EU Member States, November 2009 (http://fra.europa.eu/fraWebsite/attachments/ Roma Movement Comparative-final en.pdf); European Union Agency for Fundamental Rights (2009c), Housing conditions of Roma and Travellers in the European Union, Comparative Report, October 2009 (http://www.fra.europa.eu/fraWebsite/attachments/ROMA-Housing-Comparative-Report en.pdf); European Parliament (2008), The social situation of the Roma and their improved access to the labour market in the EU, Policy Department Economic and Scientific Policy, PE 408.582, 2008 (http://www.europarl.europa.eu/ activities/committees/studies/download.do?file=23375); E. Cahn and E. Guild (2008), Recent Migration of Roma in Europe, Council of Europe Commissioner for Human Rights and OSCE High Commissioner on National Minorities, 10 December 2008 (http://www.osce.org/documents/hcnm/2008/12/37164 en.pdf); European Monitoring Centre on Racism and Xenophobia (2006), Roma and Travellers in Public Education (http://www.fra.europa.eu/fraWebsite/attachments/roma_report.pdf); European Commission (2004), The Situation of Roma in an enlarged European Union, Directorate-General for Employment and Social Affairs (http://www.errc.org/cms/upload/media/00/E0/m000000E0.pdf). On the situation of Roma in Europe, see also M. Caparini (2010), State Protection of the Czech Roma and the Canadian Refugee System, CEPS Paper in Liberty and Security in Europe, November, and M. Merlino (2009), The Italian (In)Security Package Security vs. Rule of Law and Fundamental Rights in the EU, Challenge Research Paper No. 14, CEPS, March (http://www.ceps.eu/files/book/1809.pdf).

${ }^{74}$ S. Peers (2006), EU Justice and Home Affairs Law, Second Edition, Oxford: Oxford University Press, p. 317.

${ }^{75}$ OJ C 83/389, 30.3.2010
} 
this domain can be said to exist. Secondly, it has looked into the EU's asylum system to identify one of its key features - the prohibition for EU nationals to seek asylum in any member state as one of the possible reasons behind the decision of EU nationals in need of international protection to flee Europe in search of it in third countries.

As regards the first aspect, we have pointed out how the Commission has promptly activated the reciprocity mechanism by reporting to the Council, and we have emphasised the centrality of its role in identifying the measures that Canada and the Czech Republic will pursue in order to restore reciprocity. At the moment, it is up to the parties to make the necessary efforts to advance towards this goal. Whether the Commission would go further and propose to the Council the adoption of a (temporary) measure against Canada, would very much depend, in our view, on a substantial lack of results on Canada's side in the implementation of the agreed measures, as well as on the existence of a favourable political climate in the Council. Such a measure can only be decided by the Council acting by qualified majority. A rejection would be regarded as a failure of the EU executive, and would be interpreted as a lack of solidarity by the other member states towards the Czech Republic. At the moment, such scenario appears unlikely, as the reform of Canada's asylum system is underway, although the TRV obligation for Czechs has been in place for over a year and, despite the requests by the Czech authorities, Canada has not given any indications as to the date for its lifting.

Despite the Council's general expression of solidarity with the Czech Republic, ${ }^{76}$ the question of how far member states would be willing to go in their support remains. Bilateral relations play an important role in the relations between the EU and Canada. ${ }^{77}$ Besides, they cooperate in a wide range of policy areas, such as environment, energy, transport, trade and education. This might give the Czech Republic leverage in the negotiations for the solution of the visa issue with Canada, insofar as they succeed in linking them with the dossiers in the other policy areas in which Canadians have a particular interest, such as the Comprehensive Economic and Trade Agreement (CETA) currently under negotiation. ${ }^{78}$ Nevertheless, would the other member states agree on a measure that would not only undermine bilateral and EU relations with Canada, but could trigger a reaction that could even result in Canada imposing visas on their nationals? And how much importance would the Belgian Presidency of the Council attach to the solution of the case, given that visa reciprocity is not a priority for them $?^{79}$ In light of the above, it will be interesting to see whether Hungary, which might be the next member state for whose nationals Canada might reintroduce the TRV obligation, for the same reason as the Czech Republic, ${ }^{80}$ will be able to create the necessary conditions for the EU to react as a bloc, once they have taken over the Presidency in the first half of 2011.

As the Canada-Czech Republic visa affair has shown, visa policy and reciprocity have a strong political dimension and must be looked at in the broader context of the EU and member states'

\footnotetext{
${ }^{76}$ Press Release, $3008^{\text {th }}$ Council Meeting, Justice and Home Affairs, 8920/10 (Presse 88), Brussels, 23 April 2010 , p. 7.

${ }^{77}$ S. Alegre (2008), op. cit., p. 13.

${ }^{78}$ On 10 June 2009, the day on which negotiations were launched, Stockwell Day, former Canadian Minister of International Trade and Minister for the Asia-Pacific Gateway, said: "This first meeting represents a solid step toward a historic economic agreement between Canada and Europe. These negotiations are a priority for our government." Press Releases RAPID, "EU and Canada start negotiations for economic and trade agreement", IP/09/896, 10 June 2009 (http://europa.eu/rapid/pressReleasesAction.do?reference=IP/09/896).

79 See Belgian Presidency of the EU, Six-month programme (http://www.eu2010.be/files/bveu/media/ source1854/documents/27782 PL SPF UK.pdf).

${ }^{80}$ Informally, it is said that Canada might be considering reintroducing the TRV obligation on Hungarians too, given the rising number of asylum claims by Hungarian Roma. According to the UNHCR, 288 Hungarians applied for asylum in Canada in 2008, and 2,516 in 2009. See UNHCR (2009), op. cit.
} 
international relations. Member states' reaction to the (re)introduction of visas for the nationals of another member state by a third country whose nationals enjoy visa-free travel to the EU cannot be expected to be automatic, as decisions concerning visas are influenced by a variety of political, economic and commercial interests. This, however, challenges the principle of solidarity among member states that should guide the common visa policy.

As to the second aspect, it is to be stressed that the political debate over the Canada-Czech Republic visa affair has chiefly focused on the reciprocity dimension, whereas the fundamental rights situation of Roma as a minority in Europe, along with the impossibility for them to seek asylum in the EU, which, in our view, are the core issues behind the affair, have been overlooked. Discrimination, racist attitudes and prejudice against Roma in key areas of social life are widespread and deep in Europe. ${ }^{81}$ Further, as stressed by the Council of Europe Commissioner for Human Rights, Thomas Hammarberg, with the regard to the political debate that surrounded France's expulsion of Roma in the summer of 2010, "[...] sweeping and generalised statements about Roma from high level personalities tend to cement and deepen these prejudices". ${ }^{82}$ This situation conflicts with the principles upon which the EU is founded ${ }^{83}$ as well as with European and international anti-discrimination law. ${ }^{84}$ Canadian authorities, by reintroducing visas for Czech nationals, seem to be impeding individuals in need of international protection, as many of them were recognised by the IRB, to get into their territory lawfully and file their application. Moreover, Canada having granted asylum to Czech Roma raises questions as to the level at which some member states are complying with their EU and international human rights obligations. Hence, it is necessary to review the EU's asylum system, which is based on the presumption that fundamental rights are always respected in Europe, with a view to eliminating the prohibition for EU nationals to seek protection in any member state. This is of utmost importance also in view of the prospective accession of the EU to the Convention for the Protection of Human Rights and Fundamental Freedoms.

\footnotetext{
${ }^{81}$ According to a survey conducted by the EU Agency for Fundamental Rights in 2009, covering Bulgaria, the Czech Republic, Greece, Hungary, Poland, Romania and Slovakia, on average, $47 \%$ of all the Roma respondents indicated that they were victims of discrimination based on their ethnicity in the previous 12 months. See European Union Agency for Fundamental Rights (2009d), Data in Focus Report - The Roma, EUMidis, European Union Minorities and Discrimination Survey, 2009, p. 4.

${ }^{82}$ T. Hammarberg (2010), "Recent rise in security discourse in Europe: The case of Roma", Council of Europe Commissioner for Human Rights, Speech to the Parliamentary Assembly, Session 4 to 8 October (http://www.statewatch.org/news/2010/oct/coe-roma-security.pdf) and S. Carrera and A. Faure Atger (2010), L'affaire des Roms - A Challenge to the EU's Area of Freedom, Security and Justice, CEPS Paper in Liberty and Security in Europe, September.

${ }^{83}$ Article 2 of the Treaty on the Functioning of the European Union.

${ }^{84}$ Council Directive 2000/43/EC of 29 June 2000 implementing the principle of equal treatment between persons irrespective of racial or ethnic origin (OJ L 180/23, 19.7.2000), the Charter of Fundamental Rights of the European Union (Art. 21) (OJ C 83/389, 30.3.2010); and the Convention for the Protection of Human Rights and Fundamental Freedoms (Art. 14) (http://conventions.coe.int/treaty/Commun/ QueVoulezVous.asp?NT=005\&CL=ENG).
} 


\section{References}

\section{Bibliographical references}

Alegre, S. (2008), The EU's External Cooperation in Criminal Justice and Counter-terrorism: An Assessment of Human Rights Implications with a Particular Focus on Cooperation with Canada, CEPS Special Report, September, pp. 10-14 (http://www.ceps.eu/files/book/1705.pdf).

Bigo, D. and E. Guild (2005), "Policing at a Distance: Schengen Visa Policies", in D. Bigo and E. Guild (eds), Controlling Frontiers - Free Movement into and within Europe, Aldershot: Ashgate, pp. 244-245.

Cahn, C. and E. Guild (2008), Recent Migration of Roma in Europe, Council of Europe Commissioner for Human Rights and OSCE High Commissioner on National Minorities, 10

December (http://www.osce.org/documents/henm/2008/12/37164_en.pdf).

Caparini, M. (2010), State Protection of the Czech Roma and the Canadian Refugee System, CEPS Paper in Liberty and Security in Europe, November.

Carrera, S. and A. Faure Atger (2010), L'affaire des Roms - A Challenge to the EU's Area of Freedom, Security and Justice, CEPS Paper in Liberty and Security in Europe, September.

European Commission (2004), The Situation of Roma in an enlarged European Union, Directorate-General for Employment and Social Affairs (http://www.errc.org/cms/upload/media/00/E0/m000000E0.pdf).

European Monitoring Centre on Racism and Xenophobia (2006), Roma and Travellers in Public Education (http://www.fra.europa.eu/fraWebsite/attachments/roma report.pdf).

European Parliament (2008), The social situation of the Roma and their improved access to the labour market in the EU, Policy Department Economic and Scientific Policy, PE 408.582 (http://www.europarl.europa.eu/activities/committees/studies/ download.do?file $=23375$ ).

European Union Agency for Fundamental Rights (2009a), Annual Report 2009 (http://www.fra.europa.eu/fraWebsite/attachments/FRA-AnnualReport09 en.pdf).

European Union Agency for Fundamental Rights (2009b), The situation of Roma EU citizens moving and settling in other EU Member States, November (http://fra.europa.eu/fraWebsite/attachments/Roma Movement Comparativefinal en.pdf).

European Union Agency for Fundamental Rights (2009c), Housing conditions of Roma and Travellers in the European Union, Comparative Report, October (http://www.fra.europa.eu/fraWebsite/attachments/ROMA-Housing-ComparativeReport en.pdf).

European Union Agency for Fundamental Rights (2009d), Data in Focus Report - The Roma, EU-Midis, European Union Minorities and Discrimination Survey (http://www.fra.europa.eu/fraWebsite/attachments/EU-MIDIS_ROMA_EN.pdf).

Gil-Bazo, M.T. (2007), "Refugee Status, Subsidiary Protection and the Right to be granted Asylum under EC Law", in A. Baldaccini, E. Guild and H. Toner (eds), Whose Freedom, Security and Justice? EU Immigration and Asylum Law and Policy, Oxford: Hart Publishing, pp. 229-264. 
Goodwin-Gill, G.S. and J. McAdam (2007), The Refugee in International Law, Third Edition, Oxford: Oxford University Press, p. 61.

Guild, E. (2005), “The Legal Framework: Who is Entitled to Move?”, in D. Bigo and E. Guild (eds), Controlling Frontiers - Free Movement into and within Europe, Aldershot: Ashgate, p. 34.

Guild, E. (2003), "The Border Abroad - Visas and Borders Controls", in K. Groenendijk et al. (eds), In Search of Europe's Borders, The Hague: Kluwer Law International, pp. 87104.

Hammarberg, T. (2010), "Recent rise in security discourse in Europe: The case of Roma", Council of Europe Commissioner for Human Rights, Speech to the Parliamentary Assembly, Session 4 to 8 October (http://www.statewatch.org/news/2010/oct/coe-romasecurity.pdf).

Hobbing, P. (2008), Tracing Terrorists: The EU-Canada Agreement in PNR Matters, CEPS Special Report, September (http://www.ceps.eu/files/book/1704.pdf).

Klug, A. (2004), "Harmonization of Asylum in the European Union - Emergence of an EU Refugee System?”, German Yearbook of International Law, 47, pp. 594-628.

Lambert, H. (2006), "The EU Asylum Qualification Directive, its Impact on the Jurisprudence of the United Kingdom and International Law", International and Comparative Law Quarterly, 55, pp. 161-192.

Merlino, M. (2009), The Italian (In)Security Package - Security vs. Rule of Law and Fundamental Rights in the EU, Challenge Research Paper No. 14, CEPS, March (http://www.ceps.eu/files/book/1809.pdf).

OSCE (2010), Report on steps taken by public administration and other bodies to improve the position of the Roma minority in the Czech Republic, September 2010, RC.DEL 126/10, 6 October, p. 10 (http://www.osce.org/documents/osce/2010/10/46897 en.pdf).

Peers, S. (2006), EU Justice and Home Affairs Law, Second Edition, Oxford: Oxford University Press, p. 317.

Salter, M. (ed.) (2010), Mapping Transatlantic Security Relations - The EU, Canada and the War on Terror, Routledge.

Salter, M. and C. Mutlu (2010), Asymmetric Borders: The Canada-Czech Republic "Visa War" and the Question of Rights, CEPS Paper in Liberty and Security in Europe, November.

Scherrer, A., E.P. Guittet and D. Bigo (eds) (2010), Mobilité(s) sous Surveillance - Perspectives croissés UE-Canada, Athéna.

Tóth, J. (2010), The Incomprehensible Flow of Roma Asylum Seekers from the Czech Republic and Hungary to Canada, CEPS Paper in Liberty and Security in Europe, November.

UNHCR (2010a), Asylum Levels and Trends in Industrialized Countries 2009, 23 March, pp. 32-34 (http://www.unhcr.org/4ba7341a9.html).

UNHCR (2010b), 2009 Global Trends: Refugees, Asylum-seekers, Returnees, Internallydisplaced and Stateless Persons, Annex, Table 12, 15 June (http://www.unhcr.org/4a375c426.html).

UNHCR (2009), 2008 Global Trends: Refugees, Asylum-seekers, Returnees, Internallydisplaced and Stateless Persons, Annex, Table 12, 16 June (http://www.unhcr.org/4a375c426.html). 
Vicenová, M. (2009), Notification by the Czech Republic concerning visa reciprocity, Ambassador, Permanent Representative of the Czech Republic to the European Union, 14 July (OJ C 184/2, 6.8.2009).

\section{Legislative measures}

1951 Convention Relating to the Status of Refugees (http://www.unhcr.org/protect/PROTECTION/3b66c2aa10.pdf).

1990 Schengen Convention and Decisions adopted by the Schengen Executive Committee (OJ L 239/19, 22.9.2000).

Act of Accession of 2003 (OJ L 236/718, 23.9.2003).

Agreement between the European Union and the Federative Republic of Brazil on short-stay visa waivers for holders of ordinary passports, 13712/10, Brussels, 28 September 2010 (http://register.consilium.europa.eu/pdf/en/10/st13/st13712.en10.pdf).

Agreement between the European Union and the Federative Republic of Brazil on short-stay visa waivers for holders of diplomatic, services or official passports, 13708/10, Brussels, $28 \quad$ September 2010 (http://register.consilium.europa.eu/pdf/en/10/st13/st13708.en10.pdf).

Charter of Fundamental Rights of the European Union (OJ C 83/389, 30.3.2010).

Convention for the Protection of Human Rights and Fundamental Freedoms (http://conventions.coe.int/treaty/Commun/QueVoulezVous.asp?NT=005\&CL=ENG).

Cooperation Agreement between the Government of Canada and the European Police Office (http://www.europol.europa.eu/legal/agreements/Agreements/227746.pdf).

Council Regulation (EC) No 1244/2009 of 30 November 2009 amending Regulation (EC) No 539/2001 listing the third countries whose nationals must be in possession of visas when crossing the external borders and those whose nationals are exempt from that requirement (OJ L 336/1, 18.12.2009).

Council Regulation (EC) No. 810/2009 of 13 July establishing a Community Code on Visas (Visa Code) (OJ L 243/1, 15.9.2009).

Council Regulation (EC) No 1932/2006 of 21 December 2006 amending Regulation (EC) No 539/2001 listing the third countries whose nationals must be in possession of visas when crossing the external borders and those whose nationals are exempt from that requirement (OJ L 405/23, 30.12.2006).

Council Regulation (EC) No 1791/2006 of 20 November 2006 adapting certain Regulations and Decisions in the fields of free movement of goods, freedom of movement of persons, company law, competition policy, agriculture (including veterinary and phytosanitary legislation), transport policy, taxation, statistics, energy, environment, cooperation in the fields of justice and home affairs, customs union, external relations, common foreign and security policy and institutions, by reason of the accession of Bulgaria and Romania (OJ L 363/1, 20.12.2006).

Council Regulation (EC) No 851/2005 of 2 June 2005 amending Regulation (EC) No 539/2001 listing the third countries whose nationals must be in possession of visas when crossing the external borders and those whose nationals are exempt from that requirement as regards the reciprocity mechanism (OJ L 141/3, 4.6.2005). 
Council Directive 2005/85/EC of 1 December 2005 on minimum standards on procedures in Member States for granting and withdrawing refugee status (OJ L 326/13, 13.12.2005).

Council Directive 2004/83/EC of 29 April 2004 on minimum standards for the qualification and status of third country nationals or stateless persons as refugees or as persons who otherwise need international protection and the content of the protection granted (OJ L 304/12, 30.9.2004).

Council Regulation (EC) No 453/2003 of 6 March 2003 amending Regulation (EC) No $539 / 2001$ listing the third countries whose nationals must be in possession of visas when crossing the external borders and those whose nationals are exempt from that requirement (OJ L 69/10, 13.3.2003).

Council Regulation (EC) No 343/2003 of 18 February 2003 establishing the criteria and mechanisms for determining the Member State responsible for examining an asylum application lodged in one of the Member States by a third-country national (OJ L 50/1, 25.2.2003).

Council Directive 2003/9/EC of 27 January 2003 laying down minimum standards for the reception of asylum seekers (OJ L 31/18, 6.2.2003).

Council Regulation (EC) No 2414/2001 of 7 December 2001 amending Regulation (EC) No $539 / 2001$ listing the third countries whose nationals must be in possession of visas when crossing the external borders of Member States and those whose nationals are exempt from that requirement (OJ L 327/1, 12.12.2001).

Council Regulation (EC) 539/2001 of 15 March 2001 listing the third countries whose nationals must be in possession of visas when crossing the external borders and those whose nationals are exempt from that requirement (OJ L/1 81 of 21.3.2001).

Council Directive 2000/43/EC of 29 June 2000 implementing the principle of equal treatment between persons irrespective of racial or ethnic origin (OJ L 180/23, 19.7.200).

Protocol (24) on asylum for nationals of Member States of the European Union (OJ C 83/305, 30.3.2010).

Regulation (EU) No 439/2010 of the European Parliament and of the Council of 19 May 2010 establishing a European Asylum Support Office (OJ L 132/11, 29.5.2010).

Treaty on the Functioning of the European Union (OJ C 83/47, 30.3.2010).

\section{Official documents}

Council of the European Union

Belgian Presidency of the EU, Six-month programme (http://www.eu2010.be/files/bveu/media/source1854/documents/27782_PL_SPF_UK.pdf ).

Press Release, 3034 ${ }^{\text {th }}$ Council Meeting, Justice and Home Affairs, 14423/10 (Presse 262), $\begin{array}{llllll}\text { Luxembourg, } & 7-8 & \text { October } & 2010, & \text { p. } & 15\end{array}$ (http://www.consilium.europa.eu/uedocs/cms_data/docs/pressdata/en/jha/116982.pdf).

Press Release, 2998 ${ }^{\text {th }}$ Council Meeting, Justice and Home Affairs, 6855/1/10 REV 1 (Presse 42), Brussels, 25-26 February 2010, p. 9 (http://www.consilium.europa.eu/uedocs/cms data/docs/pressdata/en/jha/113068.pdf). 
Press Release, $3008^{\text {th }}$ Council Meeting, Justice and Home Affairs, 8920/10 (Presse 88), $\begin{array}{lllll}\text { Brussels, } & 23 & \text { April } & 2010, & \text { p. }\end{array}$ (http://www.consilium.europa.eu/uedocs/cms Data/docs/pressdata/en/jha/113967.pdf).

Press Release, $3018^{\text {th }}$ Council Meeting, Justice and Home Affairs, 10630/1/10 REV 1 (Presse 161), Luxembourg, $3-4 \quad$ June $2010, \quad$ p. 27 (http://www.consilium.europa.eu/uedocs/cms_data/docs/pressdata/en/jha/114900.pdf).

Press Release, $2958^{\text {th }}$ Council Meeting, External Relations, 12354/09 (Presse 229), Brussels, 27 July 2009, p. 12 (http://www.consilium.europa.eu/uedocs/cms_data/docs/pressdata/en/gena/109451.pdf).

Press Release, $2960^{\text {th }}$ Council Meeting, External Relations, 13027/09 (Presse 260), Brussels, 14 September 2009, p. $\quad 8$ (http://register.consilium.europa.eu/pdf/en/09/st13/st13027.en09.pdf).

Press Release, 2962 ${ }^{\text {nd }}$ Council Meeting, Justice and Home Affairs, 13467/09 (Presse 271), $\begin{array}{lllll}\text { Brussels, } & 21 & \text { September } & 2009, & \text { p. }\end{array}$ (http://www.consilium.europa.eu/uedocs/cms_data/docs/pressdata/en/jha/110272.pdf).

European Commission

European Commission (2010a), Commission Decision establishing the Handbook for the processing of visa applications and the modification of issued visas, C(2010) 1620 final, Brussels, 19.3.2010.

European Commission (2010b), Proposal for a Regulation of the European Parliament and of the Council of the European Union amending Regulation (EC) No 539/2001 listing the third countries whose nationals must be in possession of visas when crossing the external borders of Member States and those whose nationals are exempt from that requirement, COM (2010) 256 final, Brussels, 27.5.2010.

European Commission (2010c), Commission Staff Working Document on the fulfilment of the open benchmarks by Albania and Bosnia and Herzegovina in the framework of the Commission Proposal for a Council Regulation amending Regulation (EC) No 539/2001 listing the third countries whose nationals must be in possession of visas when crossing the external borders and those whose nationals are exempt from that requirement, SEC (2010) 1085 final, Brussels, 14.09.2010.

European Commission (2010d), Communication from the Commission to the European Parliament, the Council, the European Economic and Social Committee and the Committee of the Regions, Delivering an area of freedom, security and justice for Europe's citizens - Action Plan Implementing the Stockholm Programme, COM (2010) 171 final, 20.4.2010, pp. 46-47.

European Commission (2009a), Report from the Commission to the Council on the reintroduction of the visa requirement by Canada for citizens of the Czech Republic, COM (2009) 562 final, Brussels, 19.10.2009.

European Commission (2009b), Fifth Report from the Commission to the Council and the European Parliament on certain third countries' maintenance of visa requirement in breach of the principle of reciprocity, $\operatorname{COM(2009)} 560$ final, Brussels, 19.10.2009.

European Commission (2008), Fourth Report from the Commission to the Council and the European Parliament on certain third countries' maintenance of visa requirement in breach of the principle of reciprocity, $\operatorname{COM}(2008) 486$ final/2, Brussels, 9.9.2008. 
European Commission (2007), Third Report from the Commission to the Council and the European Parliament on certain third countries' maintenance of visa requirement in breach of the principle of reciprocity, $\operatorname{COM(2007)} 533$ final, Brussels, 13.9.2007.

European Commission (2006a), First Report from the Commission to the Council and the European Parliament on certain third countries' maintenance of visa requirement in breach of the principle of reciprocity, $\operatorname{COM(2006)} 3$ final, Brussels, 10.1.2006.

European Commission (2006b), Second Report from the Commission to the Council and the European Parliament on certain third countries' maintenance of visa requirement in breach of the principle of reciprocity, $\operatorname{COM(2006)} 568$ final, Brussels, 3.10.2006.

European Commission (2004), Proposal for a Council Regulation amending Regulation (EC) No 539/2001 as regards the reciprocity mechanism, COM (2004) 437 final/2, Brussels, 19.7.2004.

European Commission (2000), Proposal for a Council Regulation listing third countries whose nationals must be in possession of visas when crossing the external borders and those nationals are exempt from that requirement, COM (2000) 27 final, Brussels, 26.1.2000.

European Parliament

European Parliament (2010a), Resolution of 5 May 2010 on the upcoming EU-Canada Summit on 5 May 2010, P7_TA-PROV(2010)0142.

European Parliament (2010b), Position of the European Parliament adopted at first reading on 7 October 2010 with a view to the adoption of Regulation (EU) No .../2010 of the European Parliament and of the Council amending Council Regulation (EC) No 539/2001 listing the third countries whose nationals must be in possession of visas when crossing the external borders and those whose nationals are exempt from that requirement, P7_TC1-COD(2010)0137.

European Union and Canada

Declaration, EU-Canada Summit, Prague, 6 May 2009, 9547/09 (Presse 120) (http://www.consilium.europa.eu/uedocs/cms data/docs/pressdata/en/er/107542.pdf).

$\begin{array}{llll}\text { Declaration on } & \text { Transatlantic } & \text { Relations, }\end{array}$ (http://www.delcan.ec.europa.eu/en/eu_and_canada/official_documents/instruments/euca dtr_1990.shtml).

EU-Canada Partnership Agenda, EU-Canada Summit, Ottawa, 18 March 2004, (http://ec.europa.eu/external_relations/canada/docs/partnership agenda_en.pdf).

Joint Declaration, Canada-European Union Summit, 19 June 2005 (http://ec.europa.eu/external_relations/canada/docs/2005 niagara on lake en.pdf).

Joint Statement, EU-Canada Summit, Video-conference London-Ottawa, November 24, 2005, (http://ec.europa.eu/external_relations/canada/docs/2005_london_en.pdf).

Press Statement, EU-Canada Summit, Council of the European Union, 9355/10 (Presse 100), Brussels, $\quad 5 \quad$ May $2010, \quad$ p. 2 (http://www.consilium.europa.eu/uedocs/cms data/docs/pressdata/en/er/114195.pdf).

Statement, EU-Canada Summit, Berlin, 4 June 2007 (http://www.eu2007.de/en/News/download_docs/Juni/0604-RAA1/010Erklaerung.pdf).

Government of Canada 
Citizenship and Immigration Canada (CIC), Operational Bulletin 168, Enhanced visa services offered in the Czech Republic, December 18, 2009 (http://www.cic.gc.ca/English/resources/manuals/bulletins/2009/ob168.asp\#tphp\%20idt php).

\section{Other documents}

CBC News, "Canada defends visa change for Mexicans, Czechs", 14 July 2009 (http://www.cbc.ca/world/story/2009/07/14/czech-visas-mexico.html).

Citizenship and Immigration Canada (CIC), News Release, "The Balanced Refugee Reform Act moves closer to become law", Ottawa, 15 June 2010 (http://www.cic.gc.ca/english/department/media/releases/2010/2010-06-15a.asp).

Citizenship and Immigration Canada (CIC), News Release, "Canada imposes a visa on the Czech Republic" (http://www.cic.gc.ca/english/department/media/releases/2009/200907-13a.asp).

Citizenship and Immigration Canada (CIC), Backgrounder, "The visa requirement for the Czech Republic" (http://www.cic.gc.ca/english/department/media/backgrounders/2009/200907-13a.asp).

Le Monde, "La France freine la levée des visas pour les Albanais et les Bosniaques", 01.10 .2010 (http://abonnes.lemonde.fr/cgibin/ACHATS/ARCHIVES/archives.cgi?ID=50d95f14bda80e2c79630461 f0bfcfb41c7fe 126729d160c\&print $=1$ ).

Press Releases RAPID, "EU and Canada start negotiations for economic and trade agreement, IP/09/896, 


\section{Annexes}

Annex 1. Political and legal developments in the EU-Canada visa dialoguesince the 2004 EU enlargement to the present

The purpose of this Annex is to provide an overview of the major developments in the EUCanada dialogue on visas since 2004. To this end, key political and legal facts have been listed in a chronological order since the adoption of the 2004 EU-Canada Partnership Agenda.

\begin{tabular}{|c|c|}
\hline \multicolumn{2}{|r|}{2004} \\
\hline & EU-Canada Partnership Agenda (Ottawa) \\
\hline 18 March 2004 & $\begin{array}{l}\text { Stepping up cooperation on justice and home affairs, including migration, } \\
\text { asylum and integration, is one of the objectives laid down in the EU-Canada } \\
\text { Partnership Agenda }\end{array}$ \\
\hline \multicolumn{2}{|r|}{2005} \\
\hline & EU-Canada Summit (Niagara-on-the-Lake) \\
\hline 19 June 2005 & $\begin{array}{l}\text { EU and Canadian leaders recognised that that measures that facilitate travel for } \\
\text { business and tourism are important drivers for the economy, and committed to } \\
\text { engage in a dialogue on visa-free travel for citizens between all the EU } \\
\text { member states and Canada. }\end{array}$ \\
\hline & EU-Canada Summit, video conference London-Ottawa \\
\hline 24 November 2005 & $\begin{array}{l}\text { At the video-conference London-Ottawa, EU and Canadian leaders agreed } \\
\text { upon taking forward "a transparent process of intensified dialogue on } \\
\text { establishing visa-exempt travel for citizens of all EU Member States and } \\
\text { Canada". }\end{array}$ \\
\hline \multicolumn{2}{|r|}{2006} \\
\hline \multirow{3}{*}{10 January 2006} & $\begin{array}{l}\text { First Report from the Commission to the Council and the European } \\
\text { Parliament on certain third countries' maintenance of visa requirement in } \\
\text { breach of the principle of reciprocity }\end{array}$ \\
\hline & $\begin{array}{l}\text { The Commission noted that, following a review of the visa waiver scheme by } \\
\text { CIC in 2004, concerning seven EU member states (the Czech Republic, } \\
\text { Estonia, Latvia, Lithuania, Hungary, Poland and Slovakia), none of them had } \\
\text { the visa requirement lifted. }\end{array}$ \\
\hline & $\begin{array}{l}\text { Further, by arguing that the Member States concerned had been assessed on } \\
\text { the basis of significantly different questionnaires, the Commission concluded } \\
\text { that there was no certainty as to the criteria used by Canada for visa } \\
\text { exemption. Canadian authorities confirmed that the review had been conducted } \\
\text { on a country-by-country basis and that it had taken into consideration the } \\
\text { reforms and changes that had taken place in those member states. }\end{array}$ \\
\hline 28 June 2006 & $\begin{array}{l}\text { Letter by the government of Canada to the Commission proposing the } \\
\text { creation of a working group on visas within a wider framework for } \\
\text { cooperation between CIC and the former Commission's DG JFS }\end{array}$ \\
\hline 27 September 2006 & Lifting of the Canada TRV requirement for Estonian citizens \\
\hline
\end{tabular}




\begin{tabular}{|c|c|}
\hline \multirow[b]{2}{*}{3 October 2006} & $\begin{array}{l}\text { Second Report from the Commission to the Council and the European } \\
\text { Parliament on certain third countries' maintenance of visa requirement in } \\
\text { breach of the principle of reciprocity }\end{array}$ \\
\hline & $\begin{array}{l}\text { The Commission recognised that non-reciprocity problems had not been } \\
\text { solved, as the visa requirement was in place for six member states (the Czech } \\
\text { Republic, Latvia, Lithuania, Hungary, Poland and Slovakia). Yet it welcomed } \\
\text { the decision of the government of Canada to lift the visa requirement on } \\
\text { Estonian citizens - which it regarded as a tangible proof of its will to advance } \\
\text { towards the full reciprocity - as well as its proposal for a new framework of } \\
\text { dialogue on visas. It also acknowledged their commitment to improve } \\
\text { transparency as to the criteria and conditions that member states must fulfil to } \\
\text { be eligible for the visa waiver. Hence the Commission estimated that no } \\
\text { measures against Canada were to be taken. }\end{array}$ \\
\hline \multicolumn{2}{|r|}{2007} \\
\hline \multirow[b]{2}{*}{4 June 2007} & EU-Canada Summit (Berlin) \\
\hline & $\begin{array}{l}\text { EU and Canadian leaders reiterated their commitment to achieve visa } \\
\text { exemption for the nationals of all EU member states as soon as possible. To } \\
\text { this end, the government of Canada committed itself to further clarify the } \\
\text { criteria and processes to achieve visa-free travel to Canada. Yet the Canadian } \\
\text { Prime Minister emphasised that Canada based its decisions on the assessment } \\
\text { of each country's circumstances, and not on reciprocity, and that, in this } \\
\text { respect, cross-border travel between the US and Canada was a very important } \\
\text { element. }\end{array}$ \\
\hline \multirow[b]{2}{*}{20 July 2007} & First Joint Consultation on Immigration and Asylum Issues \\
\hline & $\begin{array}{l}\text { At the Joint Visa Working Group meeting, Canadian authorities outlined their } \\
\text { review of the visa waiver criteria and declared that they would engage in } \\
\text { technical visits to each of the EU member states which did not benefit from } \\
\text { visa reciprocity yet. }\end{array}$ \\
\hline \multirow[b]{2}{*}{13 September 2007} & $\begin{array}{l}\text { Third Report from the Commission to the Council and the European } \\
\text { Parliament on certain third countries' maintenance of visa requirement in } \\
\text { breach of the principle of reciprocity }\end{array}$ \\
\hline & $\begin{array}{l}\text { The Commission acknowledged that, albeit with considerable delay, Canadian } \\
\text { authorities had made the revision process more transparent by providing } \\
\text { information on the criteria for attaining the visa waiver. Nevertheless, it } \\
\text { regretted that the visa requirement had not been lifted for any member state } \\
\text { since Estonia in September } 2006 \text {, and proposed that further tangible progress } \\
\text { towards full reciprocity would be made in the first half of } 2008 \text {, under the } \\
\text { threat of considering taking appropriate steps against Canada. }\end{array}$ \\
\hline \multirow[t]{2}{*}{31 October 2007} & $\begin{array}{l}\text { Lifting of the Canada TRV requirement for the nationals of the Czech } \\
\text { Republic and Latvia }\end{array}$ \\
\hline & 2008 \\
\hline \multirow{2}{*}{29 February 2008} & $\begin{array}{l}\text { Lifting of the Canada TRV requirement for the nationals of Hungary, } \\
\text { Lithuania, Poland and Slovakia }\end{array}$ \\
\hline & $\begin{array}{l}\text { With regard to Lithuania and Poland, the visa waiver applies only for the } \\
\text { holders of biometric passports, as from } 1 \text { January } 2009 \text {. }\end{array}$ \\
\hline
\end{tabular}




\begin{tabular}{|c|c|}
\hline & $\begin{array}{l}\text { Fourth Report from the Commission to the Council and the European } \\
\text { Parliament on certain third countries' maintenance of visa requirement in } \\
\text { breach of the principle of reciprocity }\end{array}$ \\
\hline 9 September 2008 & $\begin{array}{l}\text { The Commission noted that the visa requirement was still in place for the } \\
\text { nationals of Bulgaria and Romania. Yet it welcomed the lifting of the visa } \\
\text { requirement for the nationals of Czech Republic, Latvia, Hungary, Lithuania, } \\
\text { Poland and Slovakia. The Commission committed itself to pursue discussions } \\
\text { with Canada with a view to lifting the visa requirement also for the nationals } \\
\text { of Romania and Bulgaria as well as to recognising the same status for the } \\
\text { passports of all the EU member states. }\end{array}$ \\
\hline \multicolumn{2}{|r|}{2009} \\
\hline \multirow[b]{2}{*}{6 May 2009} & EU-Canada Summit (Prague) \\
\hline & $\begin{array}{l}\text { EU and Canada leaders reiterated the objective to enhance the free and secure } \\
\text { movement of people between the EU and Canada, with a view to extending as } \\
\text { soon as possible visa-free travel to Canada for all EU citizens. }\end{array}$ \\
\hline 13 July 2009 & $\begin{array}{l}\text { Official announcement by Jason Kenney, Canada's Minister of } \\
\text { Citizenship, Immigration and Multiculturalism, of the re-introduction of } \\
\text { the TRV requirement for the nationals of the Czech Republic }\end{array}$ \\
\hline \multirow[b]{2}{*}{14 July 2009} & $\begin{array}{l}\text { Declarations of Jason Kenney, Canada's Minister of Citizenship, } \\
\text { Immigration and Multiculturalism, in an interview with CBC }\end{array}$ \\
\hline & $\begin{array}{l}\text { Minister Kenney defended the reintroduction of the visa requirement for Czech } \\
\text { (and Mexican) citizens by saying that "We're not talking about the kinds of } \\
\text { people that are living in UN refugee camps by the millions who are victims of } \\
\text { war or State-sponsored prosecution [...] It is an insult to the important concept } \\
\text { of refugee protection to allow it be systematically violated by people who are } \\
\text { overwhelmingly economic immigrants". }\end{array}$ \\
\hline 14 July 2009 & $\begin{array}{l}\text { Notification to the Council and the Commission by Milena Vicenová, } \\
\text { Permanent Representative of the Czech Republic to the European Union, } \\
\text { of Canada's reintroduction of the visa requirement for the Czech } \\
\text { nationals }\end{array}$ \\
\hline 16 July 2009 & $\begin{array}{l}\text { Introduction of the visa requirement for the holders of Canadian } \\
\text { diplomatic and service passports by the government of the Czech } \\
\text { Republic }\end{array}$ \\
\hline 10 September 2009 & $\begin{array}{l}\text { Establishment and first meeting of the Canada-Czech Republic Experts } \\
\text { Working Group (Ottawa) }\end{array}$ \\
\hline \multirow{2}{*}{19 October 2009} & $\begin{array}{l}\text { Fifth Report from the Commission to the Council and the European } \\
\text { Parliament on certain third countries' maintenance of visa requirement in } \\
\text { breach of the principle of reciprocity }\end{array}$ \\
\hline & $\begin{array}{l}\text { The Commission noted that Canada still maintained the TRV requirement for } \\
\text { the nationals of Bulgaria and Romania and that it had reintroduced it for the } \\
\text { nationals of the Czech Republic as of } 14 \text { July } 2009 \text {. }\end{array}$ \\
\hline 19 October 2009 & $\begin{array}{l}\text { Report from the Commission to the Council on the re-introduction of the } \\
\text { visa requirement by Canada for citizens of the Czech Republic }\end{array}$ \\
\hline
\end{tabular}




\begin{tabular}{|c|c|}
\hline 21 December 2009 & $\begin{array}{l}\text { Canada Immigration and Citizenship (CIC) Operational Bulletin no. } 168 \\
\text { stating that Canada's visa-issuing facilities had been reinstated in Prague }\end{array}$ \\
\hline & 2010 \\
\hline 25-26 February 2010 & $\begin{array}{l}\text { EU Justice and Home Affairs Council } \\
\text { The Council called for the early restoration of visa-free travel for Czech } \\
\text { nationals to Canada. }\end{array}$ \\
\hline 15 March 2010 & $\begin{array}{l}\text { Second meeting of the Canada-Czech Republic Experts Working Group } \\
\text { (Prague) }\end{array}$ \\
\hline 23 April 2010 & $\begin{array}{l}\text { EU Justice and Home Affairs Council } \\
\text { The Council expressed solidarity to the Czech Republic and renewed its call } \\
\text { for the early restoration of visa free travel for the Czech nationals to Canada. }\end{array}$ \\
\hline 5 May 2010 & $\begin{array}{l}\text { European Parliament's Resolution on the EU-Canada Summit of } 5 \text { May } \\
2010 \\
\text { The European Parliament expressed its concern over the situation of non } \\
\text { reciprocity between Canada, Bulgaria, the Czech Republic and Romania, and } \\
\text { called for the swift lifting of the TRV obligation for the nationals of those } \\
\text { countries. }\end{array}$ \\
\hline 5 May 2010 & $\begin{array}{l}\text { EU-Canada Summit (Brussels) } \\
\text { Canada's Prime Minister Stephen Harper, the President of the European } \\
\text { Council Herman van Rompuy and the President of the Commission José } \\
\text { Manuel Barroso reaffirmed their commitment to work towards the } \\
\text { achievement of visa-free travel to Canada for all the EU citizens. }\end{array}$ \\
\hline 14 May 2010 & $\begin{array}{l}\text { Third meeting of the Canada-Czech Republic Experts Working Group } \\
\text { (Ottawa) }\end{array}$ \\
\hline 3-4 June 2010 & $\begin{array}{l}\text { EU Justice and Home Affairs Council } \\
\text { The Council called again for the early restoration of visa-free travel for the } \\
\text { Czech nationals to Canada. }\end{array}$ \\
\hline 20 September 2010 & $\begin{array}{l}\text { Fourth meeting of the Canada-Czech Republic Experts Working Group } \\
\text { (Prague) }\end{array}$ \\
\hline 7-8 October 2010 & $\begin{array}{l}\text { EU Justice and Home Affairs Council } \\
\text { At the request of the Czech Republic, the Council was informed about the } \\
\text { ongoing discussions regarding the reintroduction by Canada of the TRV } \\
\text { requirement for Czech nationals. } \\
\text { The Council invited the Commission to continue the dialogue with the } \\
\text { Canadian authorities with a view to lifting the TRV requirement as soon as } \\
\text { possible. }\end{array}$ \\
\hline
\end{tabular}




\section{Annex 2. EU legal framework on visas}

\section{Adopted measures}

1. Convention implementing the Schengen Agreement of 14 June 1985 between the Governments of the States of the Benelux Economic Union, the Federal Republic of Germany and the French Republic on the gradual abolition of checks at their common borders (OJ L 239, 22.9.2000, pp. 19-62)

2. Council Regulation (EC) No 1683/95 of 29 May 1995 laying down a uniform format for visas (OJ L 164, 14.7.1995, pp. 1-4)

- Amended by Council Regulation (EC) No 334/2002 of 18 February 2002 (OJ L 53, 23.2.2002, pp. 7-8)

- Amended by Council Regulation (EC) No 856/2008 of 24 July 2008 (OJ L 235, 2.9.2008, pp. 1-4)

3. Council Regulation (EC) No $2317 / 95$ of 25 September 1995 determining the third countries whose nationals must be in possession of visas when crossing the external borders of the Member States (OJ L 234, 3.10.1995, pp. 1-3), annulled by the Court of Justice (Judgment of 10 June 1997 in Case C-392/95: European Parliament $v$ Council of the European Union)

4. Council Regulation (EC) No 574/1999 of 12 March 1999 determining the third countries whose nationals must be in possession of visas when crossing the external borders of the Member States (OJ L 72, 18.3.1999, pp. 2-5)

5. Common Consular Instructions on Visas for the Diplomatic Missions and Consular Posts (OJ C 326, 22.12.2005, pp. 1-149)

6. Council Regulation (EC) No 539/2001 of 15 March 2001 listing the third countries whose nationals must be in possession of visas when crossing the external borders and those whose nationals are exempt from that requirement (OJ L 81, 21.3.2001, pp. 1-7)

- Amended by Council Regulation (EC) No 2414/2001 of 7 December 2001, moving Romania to the list of countries whose nationals are exempt from the visa requirement (OJ L 327, 12.12.2001, pp. 1-2)

- Amended by Council Regulation (EC) No 453/2003 of 6 March 2003, moving Ecuador to the list of countries whose nationals are required to be in possession of a visa (OJ L 69, 13.3.2003, pp. 10-11)

- Amended by Act of accession of 2003, Annex II, point 18 (B), (OJ L 236, 23.9.2003, p. 718)

- Amended by Council Regulation (EC) No 851/2005 of 2 June 2005 amending Regulation (EC) No 539/2001 listing the third countries whose nationals must be in possession of visas when crossing the external borders and those whose nationals are exempt from that requirement as regards the reciprocity mechanism (OJ L 141, 4.6.2005, pp. 3-5)

- Amended by Council Regulation (EC) No 1791/2006 of 20 November 2006 adapting certain Regulations and Decisions in the fields of free movement of goods, freedom of movement of persons, company law, competition policy, agriculture (including veterinary and phytosanitary legislation), transport policy, 
taxation, statistics, energy, environment, cooperation in the fields of justice and home affairs, customs union, external relations, common foreign and security policy and institutions, by reason of the accession of Bulgaria and Romania (OJ L 363, 20.12.2006, pp. 1-80)

- Amended by Council Regulation (EC) No 1932/2006 of 21 December 2006, moving Bolivia to the list of countries whose nationals are required to be in possession of a visa (OJ L 405, 30.12.2006, pp. 23-34)

- Amended by Council Regulation (EC) No 1244/2009 of 30 November 2009, moving the Former Yugoslav Republic of Macedonia, Montenegro and Serbia to the list of countries whose nationals are exempt from the visa requirement (OJ L $336,18.12 .2009$, pp. 1-3)

7. Council Regulation (EC) No 789/2001 of 24 April 2001 reserving to the Council implementing powers with regard to certain detailed provisions and practical procedures for examining visa applications (OJ L 116, 26.4.2001, pp. 2-4)

8. Council Regulation (EC) No 1091/2001 of 28 May 2001 on freedom of movement with a long-stay visa (OJ L 150, 6.6.2001, pp. 4-5)

9. Council Regulation (EC) No 333/2002 of 18 February 2002 on a uniform format for forms for affixing the visa issued by Member States to persons holding travel documents not recognised by the Member State drawing up the form (OJ L 53, 23.2.2002, pp. 4-6)

10. Council Regulation (EC) No 415/2003 of 27 February 2003 on the issue of visas at the border, including the issue of such visas to seamen in transit (OJ L 64, 7.3.2003, pp. 1-8)

11. Council Regulation (EC) No 693/2003 of 14 April 2003 establishing a specific Facilitated Transit Document (FTD), a Facilitated Rail Transit Document (FRTD) and amending the Common Consular Instructions and the Common Manual (OJ L 99, 17.4.2003, pp. 8-14)

12. Council Regulation (EC) No 694/2003 of 14 April 2003 on uniform formats for Facilitated Transit Documents (FTD) and Facilitated Rail Transit Documents (FRTD) provided for in Regulation (EC) No 693/2003 (OJ L 99, 17.4.2003, pp. 15-21)

13. Council Regulation (EC) No $1295 / 2003$ of 15 July 2003 relating to measures envisaged to facilitate the procedures for applying for and issuing visas for members of the Olympic family taking part in the 2004 Olympic or Paralympic Games in Athens (OJ L 183, 22.7.2003, pp. 1-5)

14. Council Regulation (EC) No 2252/2004 of 13 December 2004 on standards for security features and biometrics in passports and travel documents issued by Member States (OJ L $385,29.12 .2004$, pp. 1-6)

- Amended by Regulation (EC) No 444/2009 of the European Parliament and of the Council of 28 May 2009 (OJ L 142, 6.6.2009, pp. 1-4)

15. Council Decision 2004/512/EC of 8 June 2004 establishing the Visa Information System (VIS) (OJ L 213, 15.6.2004, pp. 5-7)

16. Recommendation 2005/761/EC of the European Parliament and of the Council of 28 September 2005 to facilitate the issue by the Member States of uniform short-stay visas for researchers from third countries travelling within the Community for the purpose of carrying out scientific research (OJ L 289, 31.11.2005, pp. 23-25)

17. Regulation (EC) No 2046/2005 of the European Parliament and of the Council of 14 December 2005 relating to measures envisaged to facilitate the procedures for applying 
for and issuing visas for members of the Olympic family taking part in the 2006 Olympic and/or Paralympic Winter Games in Turin (OJ L 334, 20.12.2005, pp. 1-6)

18. Regulation (EC) No 1931/2006 of the European Parliament and of the Council of 20 December 2006 laying down rules on local border traffic at the external land borders of the Member States and amending the provisions of the Schengen Convention (OJ L 405, 30.12.2006, pp. 1-22)

19. Regulation (EC) No 562/2006 of the European Parliament And of the Council of 15 March 2006 establishing a Community Code on the rules governing the movement of persons across borders (Schengen Borders Code) (OJ L 105, 13.4.2006, pp.1-32)

- Amended by Regulation (EC) No 296/2008 of the European Parliament and of the Council of 11 March 2008 (OJ L 97, 9.4.2008, pp. 60-61)

- Amended by Regulation (EC) No 81/2009 of the European Parliament and of the Council of 14 January 2009 (OJ L 35, 4.2.2009, pp. 56-58)

20. Decision No 896/2006/EC of the European Parliament and of the Council of 14 June 2006 establishing a simplified regime for the control of persons at the external borders based on the unilateral recognition by the Member States of certain residence permits issued by Switzerland and Liechtenstein for the purpose of transit through their territory (OJ L 167, 20.6.2006, pp. 8-13)

- Amended by Decision No 586/2008/EC of the European Parliament and of the Council of 17 June 2008, taking into account the accessions of Bulgaria and Romania (OJ L 162, 21.6.2008, pp. 27-29)

21. Decision No 582/2008/EC of the European Parliament and of the Council of 17 June 2008 introducing a simplified regime for the control of persons at the external borders based on the unilateral recognition by Bulgaria, Cyprus and Romania of certain documents as equivalent to their national visas for the purposes of transit through their territories (OJ L 161, 20.6.2008, pp. 30-35)

22. Council Directive 2005/71/EC of 12 October 2005 on a specific procedure for admitting third-country nationals for the purposes of scientific research (OJ L 289, 3.11.2005, pp. 15-22)

23. Regulation (EC) No 767/2008 of the European Parliament and of the Council of 9 July 2008 concerning the Visa Information System (VIS) and the exchange of data between Member States on short-stay visas (VIS Regulation) (OJ L 218, 13.8.2008, pp. 60-81)

24. Regulation (EC) No 390/2009 of the European Parliament and of the Council of 23 April 2009 amending the Common Consular Instructions on visas for diplomatic missions and consular posts in relation to the introduction of biometrics including provisions on the organisation of the reception and processing of visa applications (OJ L 31, 28.5.2009, pp. 1-10)

25. Regulation (EC) No 810/2009 of the European Parliament and of the Council of 13 July 2009 establishing a Community Code on Visas (Visa Code) (OJ L 243, 15.9.2009, pp. 158)

26. Regulation (EU) No 265/2010 of the European Parliament and of the Council of 25 March 2010 amending the Convention Implementing the Schengen Agreement and Regulation (EC) No 562/2006 as regards movement of persons with a long-stay visa (OJ L 85, 31.3.2010, p. 1) 


\section{Proposed measures}

1. Regulation of the European Parliament and of the Council of the European Union amending Regulation (EC) No 539/2001 listing the third countries whose nationals must be in possession of visas when crossing the external borders of Member States and those whose nationals are exempt from that requirement, COM (2010) 256 final, Brussels, 27.5.2010

2. Regulation of the European Parliament and of the Council establishing an Agency for the operational management of large-scale IT systems in the area of freedom, security and justice, COM (2010) 93 final, Brussels, 19.3.2010

3. Council Regulation on the establishment of an evaluation mechanism to verify the application of the Schengen acquis, COM (2009) 102 final, 4.3.2009

4. Council Regulation amending the Convention Implementing the Schengen Agreement as regards long stay visa and alerts in the Schengen Information System, COM (2009) 90 final, 27.2.2009

5. Council Regulation lying down a uniform format for visas (codified version), COM (2008) 891 final, 19.12.2008

\section{International agreements}

1. Agreement between the European Union and the Federative Republic of Brazil on shortstay visa waivers for holders of ordinary passports, 13712/10, Brussels, 28 September 2010

2. Agreement between the European Union and the Federative Republic of Brazil on shortstay visa waivers for holders of diplomatic, services or official passports, 13708/10, Brussels, 28 September 2010

3. Agreement between the European Community and the Republic of Albania on the facilitation of the issuance of visas (OJ L 334, 19.12.2007, pp. 85-95)

4. Agreement between the European Community and Bosnia and Herzegovina on the facilitation of the issuance of visas (OJ L 334, 19.12.2007, pp. 97-107)

5. Agreement between the European Community and the Republic of Montenegro on the facilitation of the issuance of visas (OJ L 334, 19.12.2007, pp. 109-119)

6. Agreement between the European Community and the Former Yugoslav Republic of Macedonia on the facilitation of the issuance of visas (OJ L 334, 19.12.2007, pp. 125135)

7. Agreement between the European Community and the Republic of Serbia on the facilitation of the issuance of visas (OJ L 334, 19.12.2007, pp. 137-147)

8. Agreement between the European Community and the Republic of Moldova on the facilitation of the issuance of visas (OJ L 334, 19.12.2007, pp. 169-179)

9. Agreement between the European Community and the Russian Federation on the facilitation of the issuance of visas to the citizens of the European Union and the Russian Federation (OJ L 129, 17.5.2007, pp. 27-34)

10. Agreement between the European Community and Ukraine on the facilitation of the issuance of visas - Protocol - Declaration - Joint Declarations (OJ L 332, 18.12.2007, pp. 68-76) 


\section{Reports on visa reciprocity}

1. Report from the Commission to the Council and the European Parliament on certain third countries' maintenance of visa requirements in breach of the principle of reciprocity in accordance with Article 1(5) of Council Regulation (EC) No 539/2001 listing the third countries whose nationals must be in possession of visas when crossing the external borders and those whose nationals are exempt from that requirement, as amended by Council Regulation (EC) No $851 / 2005$ as regards the reciprocity mechanism, COM (2009) 562 final, 19.10.2009

2. Fifth Report from the Commission to the Council and the European Parliament on certain third countries' maintenance of visa requirements in breach of the principle of reciprocity in accordance with Article 1(5) of Council Regulation (EC) No 539/2001 listing the third countries whose nationals must be in possession of visas when crossing the external borders and those whose nationals are exempt from that requirement, as amended by Council Regulation (EC) No 851/2005 as regards the reciprocity mechanism, COM (2009) 560 final, 19.10.2009

3. Fourth Report from the Commission to the Council and the European Parliament on certain third countries' maintenance of visa requirements in breach of the principle of reciprocity in accordance with Article 1(5) of Council Regulation (EC) No 539/2001 listing the third countries whose nationals must be in possession of visas when crossing the external borders and those whose nationals are exempt from that requirement, as amended by Council Regulation (EC) No 851/2005 as regards the reciprocity mechanism, COM (2008) 486 final/2, 9.9.2008

4. Third Report from the Commission to the Council and the European Parliament on certain third countries' maintenance of visa requirements in breach of the principle of reciprocity in accordance with Article 1(5) of Council Regulation (EC) No 539/2001 listing the third countries whose nationals must be in possession of visas when crossing the external borders and those whose nationals are exempt from that requirement, as amended by Council Regulation (EC) No $851 / 2005$ as regards the reciprocity mechanism, COM (2007) 533 final, 13.09.2007

5. Second Report from the Commission to the Council and the European Parliament on certain third countries' maintenance of visa requirements in breach of the principle of reciprocity in accordance with Article 1(5) of Council Regulation (EC) No 539/2001 listing the third countries whose nationals must be in possession of visas when crossing the external borders and those whose nationals are exempt from that requirement, as amended by Council Regulation (EC) No 851/2005 as regards the reciprocity mechanism, COM (2006) 568 final, 3.10.2006

6. First Report from the Commission to the Council and the European Parliament on certain third countries' maintenance of visa requirements in breach of the principle of reciprocity in accordance with Article 1(5) of Council Regulation (EC) No 539/2001 listing the third countries whose nationals must be in possession of visas when crossing the external borders and those whose nationals are exempt from that requirement, as amended by Council Regulation (EC) No 851/2005 as regards the reciprocity mechanism, COM (2006) 3 final, 10.1.2006 


\section{Priorities for the future: ${ }^{85}$}

1. Launching a visa dialogue with Kosovo (under United Nations Security Council Resolution 1244/99)

2. Concluding visa facilitation agreements with third countries

3. Developing, implementing and evaluating the Visa Information System (VIS)

4. Adopting regional consular cooperation programmes and setting up common visa application centres

5. Exploring the possibility of introducing an EU Electronic System for Travel Authorization (ESTA)

6. Evaluating the implementation of the Visa Code

7. Assessing the possibility of establishing a common European issuing mechanism for short term visas

8. Following up the situation of visa reciprocity with third countries through regular reports

9. Keeping the list of third countries whose nationals are subject to the visa requirement in order to cross the EU's external borders under regular review

\section{Council of Europe}

European Agreement on the Abolition of Visas for Refugees, CETS No 31, of 20.4.1959, entered into force on 4.9.1960 (France denounced it on 16.9.1986 and the United Kingdom on 11.2.2003)

\footnotetext{
${ }^{85}$ European Commission (2010d), Communication from the Commission to the European Parliament, the Council, the European Economic and Social Committee and the Committee of the Regions, Delivering an area of freedom, security and justice for Europe's citizens - Action Plan Implementing the Stockholm Programme, COM (2010) 171 final, 20.4.2010, pp. 46-47.
} 



\section{About CE
Programme Structure}

Founded in Brussels in 1983, the Centre for European Policy Studies (CEPS) is among the most experienced and authoritative think tanks operating in the European Union today. CEPS serves as an leading forum for debate on EU affairs, but its most distinguishing feature lies in its strong in-house research capacity, complemented by an extensive network of partner institutes throughout the world.

\section{Goals}

- To carry out state-of-the-art policy research leading to solutions to the challenges facing Europe today.

- To achieve high standards of academic excellence and maintain unqualified independence.

- To act as a forum for discussion among stakeholders in the European policy process

- To provide a regular flow of authoritative publications offering policy analysis and recommendations.

- To build collaborative networks of researchers, policy-makers and business representatives across the whole of Europe.

- To disseminate our findings and views through our publications and public events.

\section{Assets}

- Multidisciplinary, multinational \& multicultural research team.

- Complete independence to set its own research priorities and freedom from any outside influence.

- Seven research networks, comprising numerous other highly reputable institutes, to complement and consolidate CEPS' research expertise and to extend its outreach.

- An extensive membership base of Corporate and Institutional Members, which provide expertise and practical experience and act as a sounding board for CEPS policy proposals.

\section{Research Programmes}

- $\quad$ Economic \& Social Welfare Policies

- $\quad$ Financial Markets \& Institutions

- $\quad$ Energy \& Climate Change

- Regulatory Policy

- $\quad$ EU Foreign, Security \& Neighbourhood Policy

- $\quad$ Justice \& Home Affairs

- $\quad$ Politics \& Institutions

- $\quad$ Agricultural \& Rural Policy

\section{Research Networks}

- $\quad$ European Capital Markets Institute (ECMI)

- $\quad$ European Climate Platform (ECP)

- $\quad$ European Credit Research Institute (ECRI)

- $\quad$ European Network for Better Regulation (ENBR)

- $\quad$ European Network of Economic Policy Research Institutes (ENEPRI)

- $\quad$ European Policy Institutes Network (EPIN)

- $\quad$ European Security Forum (ESF)

CEPS organises a variety of activities, involving its members and other stakeholders in the European policy debate, including national and EU-level policy-makers, academics, corporate executives, NGOs and the media. Its funding is obtained from a variety of sources, including membership fees, project research, foundation grants, conferences fees, publication sales and an annual grant from the European Commission.
E-mail: info@ceps.eu

Website: www.ceps.eu 